\title{
What is Wrong with Convertible Bonds that Provide Call Options to Third Parties?*
}

\author{
Pyung Sig Yoon ${ }^{* *}$, Professor, Chungnam National University
}

\begin{abstract}
$\langle$ Abstract $\rangle$
Callable convertible bonds (CBs) that provide call options to third parties but are not used in major economies have been issued since issuances of detachable privately placed bonds with warrants (BWs) were banned in 2013. The largest shareholders prefer callable CBs to detachable BWs as they are purchased only if call options are in the money. This study analyses the effect of call options on the announcement effects of CB issuances and conversion right exercises using 1,496 privately placed CBs issued between 2013 and 2018. The major findings are as follows. First, the announcement effects of callable CBs are significantly smaller than those of standard CBs, which indicates that providing call options to third parties is viewed negatively. Second, callable CB issuing firms have better operating performance, higher ownership of the largest shareholders, and a higher adoption rate of refixing clauses than standard CB issuing firms. Third, the announcement effects of exercising conversion rights are significantly negative and those of callable CBs are significantly more negative than those of standard CBs. In summary, the results highlight the structural problems of callable CBs and provide empirical evidence to support our hypothesis. We recommend that financial authorities ban the issuance of callable CBs.
\end{abstract}

Keywords: Callable Convertible Bond; Announcement Effect; Call Option; Conversion Announcement Effect; Privately Placed CB

JEL Classification: G14, G32, G38

* We are grateful for comments from two anonymous referees.

** Corresponding Author. Address: Chungnam National University, School of Business, 99 Daehak-ro, Yuseong-gu, Daejeon, Korea 34134; E-mail: psyoon@cnu.ac.kr; Tel: +82-42-821-5540; +82-42-821-8718.

Received: October 30, 2019; Revised: March 19, 2020 \& April 6, 2020; Accepted: April 13, 2020 


\title{
제3자에게 콜옵션을 부여하는 전환사채의 문제점에 관한 연구
}

윤 평 식 (충남대학교 교수)**

\begin{abstract}
발행회사 최대주주 등의 제 3 자에게 전환사채를 매수할 수 있는 권리인 콜옵션(매도청구권)을 부여하는 콜옵션 전환사채 $(\mathrm{CB})$ 는 분리형 신주인수권부사채(BW)가 금지된 2013년에 처음 발행된 이후 발행량이 급격하게 늘어나고 있으나, 주요 선진국에서 활용되고 있지 않는 구조이다. 최대주주는 콜옵션 $\mathrm{CB}$ 를 이용하여 콜옵션을 양도받는 것이 사모 분리형 $\mathrm{BW}$ 로부터 분리된 신주인수권을 매입하는 것보다 유리한데, 이유는 콜옵션이 내가격에 있는 경우에만 전환사채를 매수함으로써 최대주주가 손해볼 가능성이 없기 때문이다. 본 연구는 2013년부터 2018년까지 공시된 사모 전환사채 1,496건을 대상으로 콜옵션 포함여부가 발행공시효과와 전환권행사공시효과에 미치는 영향을 분석하였으며 주요 결과는 다음과 같다. 첫째, 콜옵션 $\mathrm{CB}$ 발행의 공시효과는 표준형 $\mathrm{CB}$ 발행의 공시효과보다 유의적으로 작은데 이는 콜옵션 부여에 대한 부정적인 견해를 반영한다. 둘째, 콜옵션 $\mathrm{CB}$ 를 발행한 기업은 표준형 $\mathrm{CB}$ 를 발행한 기업에 비하여 영업성과가 우수하고 발행조건이 유리하며 대주주지분율이 높고 리픽싱조항 채택비율도 높다. 셋째, 전환청구권행사의 공시효과는 유의적인 음이며, 콜옵션 $\mathrm{CB}$ 에 연관된 전환청구권 행사의 공시효과가 표준형 $\mathrm{CB}$ 의 그것보다 유의적으로 더 부정적이다. 요약하면, 본 연구는 콜옵션 $\mathrm{CB}$ 에 대한 구조적 문제점을 제시하고 이를 뒷받침하는 시장의 부정적 실증증거를 처음으로 보고한다. 이해관계자에게 콜옵션을 부여하는 사모 $\mathrm{CB}$ 의 발행은 극단적인 불공정 거래이므로 사모 분리형 $\mathrm{BW}$ 가 금지된 것처럼 발행이 금지되어야 할 것으로(즉, 발행기업만이 콜옵션을 행사할 수 있도록 제한해야 할 것으로) 판단된다.
\end{abstract}

핵심 단어 : 매도청구권, 사모 전환사채, 콜옵션, 공시효과, 전환청구권행사

JEL 분류기호: G14, G32, G38

* 본 논문에 대해 유익한 조언을 해 주신 두 분 익명의 심사자께 감사의 말씀을 드립니다.

** 연락담당 저자. 주소: 대전광역시 유성구 대학로 99, 충남대학교 경상대학 경영학부, 34134 ;

E-mail: psyoon@cnu.ac.kr; Tel: 042-821-5540; Fax: 042-821-8718. 


\section{1. 서론}

기업은 시설투자와 운영에 필요한 자본을 유상증자, 금융기관차입, 회사채발행, 사내유보이익 등을 이용하여 조달한다. 그리고 한계기업 또는 재무곤경기업은 이런 방법들에 의존하여 자금을 조달하기가 어려우므로 전환사채 $(\mathrm{CB})$ 및 신주인수권부사채 $(\mathrm{BW})$ 등 회사채에 주권 관련 옵션이 부가된 메자닌채권(mezzanine bond)을 이용하는 경향이 있다. 최근 메자닌채권 발행은 급증하고 있으며 사모 위주로 발행되고 있다.1) 전환사채와 신주인수권부사채는 공모와 사모로 발행될 수 있는데 사모로 발행되는 경우 발행의도가 왜곡되어 최대주주에 의해 악용될 여지가 발생한다. 예를 들어, 사모 분리형 신주인수권부사채는 여러 문제점으로 인하여 2013년 8월 29일 이후 발행이 금지되고 있다(공모의 경우 2015년에 발행이 허용되었음). 언급된 문제점들은 최대주주 지분확대, 재산증여, 이익추구, 시세조정, 기존주주 지분율 희석 등이다.

분리형 신주인수권부사채는 1999년부터 허용되었는데 특히 사모로 발행되는 경우 최대주주가 이를 악용할 수 있는 여지가 많았으며 시장에서의 발행규모도 2009년부터 2013년까지 급증하였다. 최대주주가 이를 악용하는 방법은 발행과 동시에 사채권자로부터 신주인수권만을 헐값에 매입 하는 것이다. Yoon(2015a)은 신주인수권이 최대주주 등에게 매각된 373건의 사모 분리형 BW를 분석하였는데 매각단가가 행사가격의 평균 4.6\%라고 한다. 또한 Yoon(2019)은 신주인수권 행사자료를 분석한 결과 최대주주 등이 신주인수권을 행사하여 실제로 실현한 수익률의 평균이 $1,441 \%$ 이며, 이중에서 $674 \%$ 포인트는 리픽싱(refixing)으로 인한 혜택이고 나머지는 터무니없이 낮은 신주인수권 매입가격에 기인한다고 판단한다. 여기서 리픽싱(refixing)은 발행 후 주가가 하락하면 행사가격을 최초행사가격의 $70 \%$ 까지(정관에 명시된 경우 액면가까지) 하향조정하는 것이다(주가가 상승하는 경우에는 조정하지 않음).2) 1999년부터 2013년까지 15년 동안 분리형 BW가 사모로 발행되었으므로 최대주주 등이 얼마나 많은 이익을 얻었는가는 Yoon(2019)의 연구로부터 충분히 추론이 가능하다.

신주인수권부사채와 전환사채의 행사가격과 전환가격이 발행시점의 주가와 연동되어 있는 상황에서, 구조적으로 분리형 신주인수권부사채에 비하여 전환사채의 경우 최대주주가 이를 악용하기가 용이하지 않다. 분리형 $\mathrm{BW}$ 의 경우 최대주주가 신주인수권만을 헐값에 매입하면 옵션의 레버리지 속성과 리픽싱을 이용하여 매우 높은 수익률을 얻는 것이 용이하다. 그러나 전환사채의 경우 많은 금액을 조달하여 전환사채를 인수하여야 하므로 같은 조건에서 동일한 수익률을 얻는 것이 어렵게 된다.

1) 메자닌채권(전환사채, 신주인수권부사채, 교환사채, 이익참가부사채 등)의 발행규모는 2013 년의 1 조 원대에서 2016년 이후 5조 원 내외의 규모로 성장하였으며, 공모발행 비중도 2011 년의 $63 \%$ 에서 2018년에는 4.3\%로 급격히 낮아졌다(김필규, 사모펀드 환매중단 사태에 따른 메자닌채권시장의 영향, 자본시장포커스 2019-22호).

2) Yoon(2015a)과 Yoon(2019)의 연구기간은 2009년 7월부터 2013년 8월까지이다. 이유는 최대주주 등이 신주인수권만을 매입하는 사례가 늘어남에 따라 금융감독원이 2009년 7월 1 일부로 신주인수권의 이론가격 및 매각계획의 기재를 의무화하였기 때문이다. 
What is Wrong with Convertible Bonds that Provide Call Options to Third Parties?

2013년 자본시장법 제 163 조의 개정으로 분리형 사모 BW가 금지됨에 따라 BW 발행 횟수와 규모는 급감하였고, 시장은 이를 대체할 수 있는 구조를 전환사채를 이용하여 만들게 되는데 이 구조가 콜옵션 전환사채(callable convertible bond)이다. 발행기업이 콜옵션을 보유하는 전환사채는 예전부터 존재했으며 국내·외에서 광범위하게 이용되고 있다. 문제가 되는 경우는 발행기업뿐만 아니라 제 3 자도 콜옵션을 행사할 수 있는 특수한 콜옵션 전환사채로 주요 선진국에서 거의 사용되고 있지 않는 구조인데, 본 연구에서 사용하는 콜옵션 전환사채는 이 경우만을 의미한다. 본 연구가 확인한 최초의 사모 콜옵션 전환사채는 2013년 10월 31일에 크루셜엠스(주)가 공시한 전환사채이다.

콜옵션은 시장에서 통상 매도청구권으로 불리는데 콜옵션의 내용은 공시자료에 대략적으로 다음과 같이 표기된다.3)

발행회사는 사채권자가 보유하고 있는 사채를 발행회사 또는 발행회사가 지정하는 제 3 자(이하 “매수인”이라 한다)에게 매도하여 줄 것을 사채권자에게 청구할 수 있으며, 사채권자는 발행회사의 청구에 따라 보유하고 있는 사채를 매수인에게 매도하여야 한다. 단, 발행회사는 각 사채권자에 대하여 각 사채권자가 보유하고 있는 사채 발행가액의 $00 \%$ 를 초과하여 매도청구권을 행사할 수 없다. 사채권자는 발행회사 또는 제 3 자의 매도청구권의 행사를 보장하기 위하여 청구권행사기간 종료일까지 발행가액의 $00 \%$ 에 대하여 중도상환청구권(put option)을 행사할 수 없으며 미전환 상태로 보유하여야 한다.

여기서 제 3 자(또는 이해관계자로 지칭함)는 보통 발행회사의 최대주주, 최대주주의 자녀 및 특수관계인으로 이해된다. 발행기업이 콜옵션을 행사하여 전환사채를 매수하는 것도 가능하지만, 기업이 콜옵션 전환사채를 발행하는 근본적인 목적은 이해관계자에게 콜옵션을 부여하기 위한 것으로 이해된다. 전환이 유리한 상황이 되면 발행기업은 이해관계자에게 콜옵션을 부여할 수 있고, 이해관계자는 콜옵션을 행사하여 $\mathrm{CB}$ 를 매수하고 이를 전환하여 주식을 시장가격보다 낮은 가격으로 매수하게 된다.

콜옵션이 내재된 전환사채는 분리형 사모 신주인수권부사채가 진화한 것으로 시장은 평가하는데, 최대주주 입장에서는 사모 분리형 $\mathrm{BW}$ 보다 사모 콜옵션 $\mathrm{CB}$ 가 보다 유리하다. 이유는 분리형 사모 BW의 경우 최대주주가 발행과 동시에 신주인수권을 매입해야 하지만,4) 콜옵션 전환사채의 경우 발행시점에서 매입할 필요가 없으며 주가가 충분히 상승하여 전환사채를

3) 발행기업 또는 이해관계자가 콜옵션을 소유하는 경우 콜옵션은 매도청구권으로 불린다. 그리고 발행기업만이 콜옵션을 소유하는 경우 콜옵션은 중도상환권 또는 조기상환권 등으로 표기된다(종종 중도상환청구권 또는 조기상환청구권으로 잘못 표기되기도 함). 그런데 사채권자가 보유한 풋옵션도 조기상환청구권으로 불리므로 시장에서 사용하는 언어가 대단히 혼란스럽다는 것을 알 수 있다.

4) 반드시 발행과 동시에 최대주주가 신주인수권을 매입해야 하는 것은 아니다. 실질적으로 최대주주가 차후에 사채권자와의 협의를 통해 신주인수권을 매입할 수도 있을 것으로 예상되나 이런 내용은 시장에 공시되지 않아 실태를 파악할 수 없다. 2009년부터 개정된 공시서식에 의하면 최대주주는 발행과 동시에 사채권자로부터 매입한 신주인수권의 거래내역은 반드시 공시해야 한다. 
한국증권학회지 제49권 3호 (2020)

전환하는 것이 유리한 시점이 되면 이해관계자는 발행기업으로부터 콜옵션을 양도받아 주식을 시가보다 낮은 가격으로 확보할 수 있기 때문이다. 이처럼 매입비용을 즉각적으로 지불하지 않아도 될 뿐만 아니라 이해관계자는 전환이 유리한 시점에 도달하는 경우에만 콜옵션을 양도받으므로 손해보지 않는다는 점에서 절대적으로 유리하다.5) 또한 최대주주가 콜옵션을 얼마에 매입하는지 전혀 공시되지 않으므로 외부의 감시기능이 제대로 작동되지 않는 많은 코스닥기업의 경우 최대주주는 아주 헐값에 또는 거의 무상에 가까운 가격으로 콜옵션을 양도받을 것으로 추정된다. 다시 말하면, 전환사채 발행시 최대주주에게 콜옵션을 보유할 수 있는 자격을 부여하면 이는 분리형 $\mathrm{BW}$ 를 발행하고 최대주주가 신주인수권을 사채권자로부터 매입한 것과 유사한 구조이면서 손해의 가능성이 전혀 없다는 점에서 '최악의 불공정 거래'로까지 극단적으로 표현할 수 있다.6)

최근 경제개혁연대가 금융감독원에 현대엘리베이터의 전환사채(2015년 11월 5일 발행공시)의 위법성 여부에 대하여 조사를 요청한 이유도 현대엘리베이터의 최대주주가 경영권 강화를 위하여 분리형 $\mathrm{BW}$ 를 우회발행한 것으로 간주하기 때문이다.7) 현대엘리베이터는 현정은회장과 현대 글로벌이 보유한 콜옵션 거래가 사실상 분리형 BW의 신주인수권에 해당된다며 2018년 5월말 금융위원회에 유권해석을 요청하였는데, 동년 11월 금융위원회는 "현행 자본시장법령은 전환사채 발행과 관련 콜옵션 부여와 양도를 제한하는 별도 규정을 두고 있지 않다”고 답변한 것으로 알려졌다.

Yoon(2015a)에 의하면 분리형 사모 신주인수권부사채를 발행한 기업들은 크게 두 가지 유형으로 구분된다. 첫 번째 유형은 자금조달이 절대적으로 필요한 한계기업으로 이 기업들은 일반적으로 최대주주가 사채권자로부터 신주인수권을 매입하지 못한다(즉, 발행기업이 자신의 절박한 사정으로 인해 사채권자와의 협상에서 협상력을 갖지 못함). 두 번째 유형은 자금조달이 절실하게 필요하지 않는 보통기업으로 제도의 허점을 이용하여 큰 이익을 얻거나 지분을 확보하고자 하는 수상한 기업인데, 이 기업들은 대체로 최대주주가 사채권자로부터 일정 비율의 신주인수권을 헐값에 매입한다(즉, 최대주주가 일정 비율의 신주인수권을 매입하는 것을 조건으로 사채권자를 찾았을 것으로 추론할 수 있음). 본 연구의 콜옵션 전환사채 발행기업도 Yoon(2015a)의 “수상한 기업”과 유사할 개연성이 있다.

5) Yoon(2019)은 분석한 사모 분리형 BW 249건 중에서 44건의 경우 신주인수권이 외가격으로 최종 마감되어 최대주주 등의 수익률이 $-100 \%$ 라고 보고한다.

6) 최대주주는 콜옵션이 외가격 상태를 유지하면 콜옵션을 양도받지 않으며 내가격에 있는 경우에만 콜옵션을 양도받아 행사하므로 행사시점 기준으로 절대 손해가 발생하지 않는다. 그러나 전환청구권을 행사한 후 전환사채가 보통주로 전환되면 실제로 신주가 상장되기까지에는 약 2-3주간의 기간이 소요되므로 이 기간에 주가가 하락하면 투자자가 손해보는 것이 가능하다. 그러나 최대주주는 전환청구권이 충분히 내가격에 있을 때 행사하여 행사 후 주가가 다소 하락하더라도 손해를 회피할 수 있으며 또한 최대주주가 갖는 정보의 우위성을 감안할 때 실제로 손실을 입을 가능성은 낮다고 판단된다.

7) 경제개혁연 대 보도자료, "금감원에 현대엘리베이터의 편법 전환사채 거래 의혹에 대한 조사요청", 2018. 5. 29. 
What is Wrong with Convertible Bonds that Provide Call Options to Third Parties?

사모 콜옵션 전환사채는 분리형 사모 신주인수권부사채의 발행이 금지된 직후 시장에 등장하였으며, 최근에 콜옵션이 부가되어 발행되는 전환사채가 급격하게 증가하고 있다. 예를 들어, 2018 년에 발행된 전환사채의 대략 $41 \%$ 가 콜옵션 전환사채이다. 금융감독원은 2016 년 12 월 9 일 r 기업공시서식 작성기준」을 개정하여 전환사채의 콜옵션에 관련된 내용을 기재하도록 요구하였다. 즉, 콜옵션을 활용해 전환사채를 취득할 경우 해당인의 성명, 회사와의 관계, 취득규모 및 목적 등을 기재해야 한다(매수자가 확정되지 않은 경우 매수자가 될 수 있는 사람). 그러나 콜옵션을 부여하는 시점이 미래이므로 발행기업은 성명, 관계, 목적 등을 미정으로 처리하고 있어 새로운 공시서식이 전혀 역할을 하지 못하고 있는 실정이다.

과거에도 금융감독원은 공시서식을 변경하여 문제점을 완화하고자 하였다. 예를 들어, 분리형 사모 BW의 여러 문제점이 대두되자 사채권자로부터 신주인수권을 매입한 당사자, 발행기업과의 관계, 매각단가 등을 공시하도록 하였으며 이는 2009년 7월부터 시행되었다. 2000년 5월 29일자 금융감독원 보도자료 “신주인수권부사채의 불공정 발행에 대한 대책 마련”에 최대주주가 신주인수권을 헐값에 매입하여 지분확대의 수단으로 악용하고 있음을 적시하고 있다. 그러나 문제점을 인식하고 실제로 이를 공시양식에 반영하기까지 9년이 소요된 셈이다. 그리고 2009년 7월부터 신주인수권 매매에 대한 자료가 공시되었지만 이런 공시의무를 부여하는 것이 BW와 연관된 여러 문제점들을 경감시키는데 전혀 도움이 되지 못하였고, 결국 감독당국은 자본시장법을 개정하여 2013년 8월부터 전면적으로 발행을 금지하게 된다.

콜옵션 $\mathrm{CB}$ 는 분리형 사모 $\mathrm{BW}$ 보다 훨씬 많은 구조적인 문제점을 가지고 있으나 전혀 통제받지 않은 상황에서 발행 규모가 계속 늘어나고 있다. 금융감독원은 기업공시서식을 개정한 것으로 모든 책임을 완수한 듯 뒷짐만지고 있다. 금융감독원은 분리형 사모 $\mathrm{BW}$ 와 같은 실수를 반복하지 않기 위해서는, 설령 현재의 자본시장법에 위반되지 않더라도, 문제가 발생하는 것을 계속 모니터링만 할 것이 아니라 발행금지와 같은 보다 강력한 조치를 취해야 한다. 발행기업이 만기일 전에, 기 발행된 전환사채를 상환하는 것은 정상적인 재무결정이므로 당연히 허용되어야 한다. 따라서 콜옵션 전환사채의 발행을 금지한다는 것은 발행기업만이 콜옵션을 보유할 수 있도록 제한하는 것을 의미한다.

본 연구는 콜옵션 전환사채가 처음 공시된 2013년 10월 31일부터 2018년 말까지 5년 2개월 동안 발행된 사모 전환사채를 표본으로 선정하고 콜옵션 전환사채의 구조적 문제점과 발행 현황 및 발행기업의 특성을 분석하고 콜옵션의 포함 여부가 전환사채발행 공시효과와 전환청구권 행사 공시효과에 미치는 영향을 분석하기로 한다.

본 연구의 주요 결과는 다음과 같다. 첫째, 콜옵션 전환사채발행의 공시효과는 표준형 전환사채(콜옵션이 부여되지 않은 전환사채)의 공시효과보다 유의적으로 작은데 이는 콜옵션 부여에 대한 부정적인 견해를 반영한다. 둘째, 콜옵션 전환사채를 발행한 기업은 표준형 전환사채를 발행한 기업에 비하여 영업성과가 우수하고 발행조건이 유리하는 등 상대적으로 우량한 기업이지만, 대주주지분율이 높고 리픽싱조항 채택비율도 높다. 대주주지분율이 높은 기업이 콜옵션 전환사채를 이용하여 지분율을 더 높이고자 하며 또한 투자자에게 유리한 리픽싱조항을 더 많이 채택한다는 것은 최대주주의 의도가 건전하다고 보기 어렵다는 것을 
한국증권학회지 제49권 3호 (2020)

의미한다. 셋째, 전환청구권행사의 공시효과는 유의적인 음이며, 콜옵션 전환사채에 연관된 전환청구권행사의 공시효과가 표준형 전환사채에 연관된 전환청구권행사의 공시효과보다 유의적으로 더 부정적으로 나타난다.

본 연구는 분리형 사모 신주인수권부사채의 발행이 2013년 금지된 이후 시장에 새로 등장한 사모 콜옵션 전환사채의 문제점과 실증증거를 처음으로 제시한다는 점에서 재무 분야의 이론과 실무 및 정책제안 측면에서 공헌하는 바가 크다고 사료된다. 금융감독원은 콜옵션 전환사채의 문제점을 면밀히 분석하여 주주들이 더 큰 피해를 입기 전에 이에 대한 대책을 강구해야 한다. 금융감독원이 사모 분리형 $\mathrm{BW}$ 를 이용한 최대주주의 불공정 거래는 규제하면서 최대주주가 사모 콜옵션 전환사채를 이용하여 동일한 유형의 불공정 거래를 하고 있음에도 이에 대해 적극적인 조치를 취하고 있지 않는 것은 납득하기 어렵다.

본 논문의 구성은 다음과 같다. 먼저 제 2장에서 선행연구를 요약하고, 제 3장에서 표본구성, 콜옵션 전환사채의 기본 구조와 문제점, 방법론, 검증가설을 소개하기로 한다. 실증 결과는 제 4장에 제시되어 있으며 제5장에서 결론과 제도적 시사점을 도출하기로 한다.

\section{2. 기존연구 요약}

\section{1 전환사채 관련 기존연구 요약}

국내 전환사채 발행에 대한 공시효과는 비유의적이거나(Kwon et al., 1992; Kho and Park, 2000; Jung and Cha, 2009), 양으로 유의적이거나(Yun and Jeong, 2001; Park and Baek, 2003; Oh and Kim, 2012; Kim and Han, 2019; Yoon, 2020), 또는 음으로 유의적으로(Woo, 1995; Kwak, 2012; Byun and Park, 2017) 나타나 연구결과가 매우 불명확하다.8)

Yun and Jeong(2001), Park and Baek(2003)은 주로 90년대의 공모발행을 주요 대상으로 분석하였으며 유의적인 양(+)의 공시효과를 보고한다. 그리고 Oh and $\operatorname{Kim}(2012)$ 은 2000년부터 2011년까지 공시된 전환사채 표본 822건을 대상으로 공시효과를 분석한 결과, 공시일을 전후한 3 일간의 누적초과수익률이 $1.87 \%$ 라고 보고한다 $(\mathrm{t}-\mathrm{value}=4.80)$. 그리고 Kim and Han(2019)은 2000 년부터 2015년까지 공시된 전환사채 표본 1,508 건을 분석한 결과 공시일을 전후한 3 일간 누적초과수익률이 $1.45 \%$ 로 $1 \%$ 신뢰수준에서 유의적이며, 시설자금조달을 목적으로 공시하는 $\mathrm{CB}$ 의 공시효과가 다른 목적의 공시효과보다 유의적으로 크다고 보고한다. Yoon(2020)은 전환사채발행표본 1,421 건의 공시효과를 검증한 결과, 전환사채발행 공시효과가 양(+)으로 유의적이라고 한다(3일간 누적초과수익률 4.66\%).

반면에 Woo(1995), Kwak(2012), Byun and Park(2017)은 유의적인 음(-)의 공시효과를 보고한다. Woo(1995)의 연구는 매우 오래전에 이루어졌지만, 남은 두 연구는 비교적 최근의 연구이고 표본 수도 그리 작지 않다. Kwak(2012)은 2001년부터 2009년까지 유가증권시장 전환사채발행 공시효과를 분석한 결과 이틀 누적초과수익률이 $-0.58 \%$ 이며 이는 $5 \%$ 신뢰수준 에서 유의적이라고 한다. 그리고 Byun and Park(2017)은 2000년부터 2015년까지 813건을

8) 전환사채발행 공시효과에 대한 보다 자세한 기존연구 요약은 Yoon(2020)을 참고하라. 
What is Wrong with Convertible Bonds that Provide Call Options to Third Parties?

대상으로 공시효과를 분석한 결과 공시일 전후 7 일간의 누적초과수익률이 $-1.05 \%$ 이며 $5 \%$ 신뢰수준에서 유의적이라고 보고한다.

외국의 경우 공시효과는 국가별로 양 또는 음으로 결과가 상이하다. 공시효과가 미국, 영국, 호주, 프랑스의 경우 음이고(Dann and Mikkelson, 1984; Eckbo, 1986; Lewis et al., 1999; Abhyankar and Dunning, 1999; Magennis et al., 1998; Burlacu, 2000), 일본과 네덜란드의 경우 양이다(Kang and Stulz, 1996; De Roon and Veld, 1998).9)

전환사채는 신용등급이 낮지만 부채비율이 높고 성장성이 좋은 신생기업이 주로 활용하는 자금조달수단으로 인식되고 있다(Eom and Cho, 2017). 전환사채를 발행하는 이유로는 이자비용 절감, 위험평가오류로부터 투자자 보호, 대리인비용 감소, 잠재적 자기자본(backdoor equity)의 역할, 세금절약효과 등이 주로 언급된다(Green, 1984; Brennan and Schwartz, 1988; Mayers, 1998; Stein, 1992; Lewis et al., 2003; Jalan and Barone-Adesi, 1995).10)

전환사채 관련하여 중요한 연구 주제가 차익거래이다. 전환사채 차익거래(convertible bond arbitrage)는 전환사채를 매수함과 동시에 주식을 공매도하는 거래로 주가변동위험을 제거하고 채권에 비해 비정상 수익을 추구하는 전략이다(Yoon, 2019). 전환사채 차익거래를 분석한 국내 연구에는 Choe and Yang(2012), Eom and Cho(2017) 등의 연구가 있으며, 외국 연구에는 Choi et al.(2009), Duca et al.(2012), Agarwal et al.(2011), Marle and Verwijmeren(2017), De Jong et al.(2011) 등이 있다.

외국에서 콜옵션 전환사채(callable $\mathrm{CB}$ )는 발행기업이 전환사채를 콜(상환)할 수 있는 권리를 갖는 $\mathrm{CB}$ 로, 이에 대한 연구는 주로 콜정책(call policy)과 콜공시효과에 집중된다.11) 완전자본시장 에서 발행기업은 전환가치(conversion value)가 콜가격(call price)을 초과하는 순간 전환사채를 상환하는 것이 최적이다(전환가치는 전환가능주식수에 주가를 곱한 가격임). 그러나 실제로 발행기업은 전환가치가 콜가격을 크게 상회하는 시점까지 콜하지 않는 콜지연현상(call delay)을 보이는데 이를 설명하는 논리로 현금흐름, 대리인비용감소, 시그널링, 거래비용 등이 제시된다 (King and Mauer, 2014; Ingersoll, 1997; Harris and Raviv, 1985). 그리고 콜공시효과는 유의적인 음으로 알려져 있다(Bechmann, 2004; Rahman and Deshpande, 1997; Bechmann et al., 2014). 본 연구에서 분석하는 콜옵션 전환사채는 발행기업뿐만 아니라 이해관계자도 콜옵션을 소유하는 새로운 형태의 $\mathrm{CB}$ 로 이에 대한 기존의 연구는 국내에서도 그리고 해외에서도 전무한 것으로 파악된다.

리픽싱조항(refixing clause)은 우리나라의 경우 전환사채와 신주인수권부사채 발행에 첨가되어 발행되며, 발행 후 주식가격이 하락하면 일정한 간격으로 최초의 전환가격 또는 행사가격 이하로(일반적으로 $70 \%$ 까지) 전환가격 또는 행사가격을 하향조정할 수 있는 조항이다(주가가 상승하더라도 상향조정되지는 않음). 리픽싱조항은 주요 선진국 중에서 우리나라와 일본에서만

9) Fields and Mais(1991)는 미국 사모 전환사채 61건의 경우 공시효과가 $1.80 \%$ 로 유의적이라고 보고한다.

10) 이들 논문에 대한 요약은 Yoon(2020)을 참고할 것.

11) 이 문단에서 콜옵션 전환사채는 발행기업만이 콜옵션을 보유하는 전환사채이다. 
한국증권학회지 제49권 3호 (2020)

활발하게 이용되는 조항이다. 미국의 경우 일부 기업에 한해 사모에서 제한적으로 사용되는데 이를 death spiral convertible bond, toxic convertible bond, floating price convertible bond 등으로 불린다(Yoon, 2020). 일본의 경우 리픽싱조항은 신주인수권부사채에는 적용되지 않고 전환사채에서 활발히 이용된다(이를 일본에서는 Moving Strike Convertible Bond(MSCB) 또는 전환가격수정조항부전환사채(轉換價格修正條項附轉換社債)로 부름(Byun and Park, 2017)). 반면에 우리나라의 경우 전환사채와 신주인수권부사채 모두에서 활발하게 이용되며 이로 인해 여러 문제점이 야기된 것도 사실이다.

Yoon(2020)은 2015년부터 2018년까지의 전환사채발행표본 1,421건을 구성하여 전환사채 발행과 전환가액조정의 공시효과를 검증한 결과, 리픽싱조항이 포함된 경우의 전환사채발행 공시효과가 리픽싱조항이 제외된 경우의 공시효과보다 유의적으로 작으며, 리픽싱조항에 의한 전환가액조정 공시효과도 음(-)으로 유의적임을 발견하였다. Yoon(2020)은 리픽싱조항의 부정적 효과를 지지하는 실증증거를 최초로 제시하며, 이 조항은 투자자에게 지나치게 유리한 조항이므로 혜택을 축소해야 한다고 주장한다.

\section{2 신주인수권부사채 관련 기존연구 요약}

신주인수권부사채발행의 공시효과와 문제점에 관한 연구는 Yoon(2015a), Yoon(2015b), Yoon(2019), Oh and Kim(2012)에 의해 수행되었다. Yoon(2015a)은 2009년 7월부터 2013년 8월 28일까지 공시된 신주인수권부사채(BW) 중에서 신주인수권이 최대주주 등에게 매각된 373 건의 사모 분리형 $\mathrm{BW}$ 를 분석하였다. 사모 $\mathrm{BW}$ 는 발행 후 1 년이 지난 시점부터 행사가 가능한데 신주인수권만을 인수한 최대주주 등이 이 시점에서 행사한다고 가정하고 수익률을 계산한 결과, 1 년 동안 평균 $460 \%$ 의 수익률을 얻는 것으로(즉, 860 억 원을 투자하여 4,000억 원대의 이익을 얻는 것으로) 분석하였다. 이 연구에서 구한 수익률은 최대주주 등이 실제로 실현한 수익률이 아니라 일정한 가정하에서 계산된 가상의 수익률이다. 그리고 $460 \%$ 의 수익률은 행사가 금지된 1년 동안 행사가격조정은 계속적으로 이루어지고 또한 행사가 가능한 첫날에 모두 행사된다는 가정에서 구한 수익률이므로 최대주주의 수익률로는 사실 과소평가된 수치이다. 놀랍게도 이 기간(발행 후 1 년) 동안 주식의 평균 수익률은 $-2 \%$ 인데 이렇게 주가가 하락하는 상황에서 최대주주 등이 평균 $460 \%$ 의 수익률을 얻을 수 있었던 이유는 레버리지효과와 리픽싱 조항 때문이라고 보고한다.

Yoon(2015b)은 2009년 7월부터 2012년 말까지 공시된 BW건을 대상으로 554건의 표본을 구성하고 장단기 공시효과를 분석하였다. 공시표본은 환매기업과 비환매기업으로 구분되는데, 여기서 환매기업이란 $\mathrm{BW}$ 발행과 동시에 대주주 등의 특수관계인과 제 3 자가 신주인수권만을 매입하는 경우를 말한다. 그는 비환매기업은 재무적 곤경이 심한 한계기업인 반면에 환매기업은 대체로 지분을 확대하고자 하는 평균 수준의 기업이며, 단기적으로 양의 공시효과 $\operatorname{CAR}(-1,1)$ $=3.72 \%)$ 와 장기적으로 음의 공시효과는 비환매기업에만 적용된다고 보고한다. 한편 $\mathrm{Oh}$ and $\operatorname{Kim}(2012)$ 은 900여 건의 분리형 신주인수권부사채 발행의 공시효과를 분석하였으며 공시일 전후 3 일간의 누적초과수익률을 $1.86 \%$ 로 보고한다. 
What is Wrong with Convertible Bonds that Provide Call Options to Third Parties?

Yoon(2019)은 2009년 7월부터 2013년 8월말까지 공시된 사모 신주인수권부사채 발행 중에서 최대주주 등의 특수관계인이 사채권자로부터 신주인수권을 매입(환매)한 249건을 대상으로 분석한 결과 $\mathrm{BW}$ 발행 공시효과가 음으로 유의적이라고 보고한다 $(\mathrm{AR} 0=-0.92 \%, \mathrm{t}-\mathrm{value}=$ -3.07). 이는 신주인수권부사채의 공시효과가 양으로 유의적이라는 또는 전혀 유의적이지 않다는 기존의 연구와 대비된다. 또한 Yoon(2019)은 최대주주 등이 신주인수권을 행사한 1,230건을 분석한 결과 실제로 얻은 평균 수익률은 $1,441 \%$ 인데 대략 절반에 해당되는 $674 \%$ 포인트는 리픽싱조항으로 인한 혜택이고 나머지는 터무니없이 낮은 신주인수권의 가격에 기인한다고 판단한다.

한편, Yoon and Choi(2018)는 BW를 발행한 기업을 대상으로 이익조정 여부를 분석한 결과 환매기업이 비환매기업에 비하여 이익조정을 유의적으로 더 많이 실시하는데 이는 최대주주가 신주인수권 행사를 통해 자신의 이익을 극대화하기 위하여 이익조정을 실시한 증거로 해석한다.

\section{3 옵션 행사시점의 선택과 공시효과에 관한 연구 요약}

Yoon(2019)은 대주주가 기업의 미래에 대해 보다 정확한 정보를 보유하므로 주가가 많이 상승한 시점에서 신주인수권을 행사할 것으로 추정되며, 실제로 -100 일부터 신주인수권 행사일 까지의 누적초과수익률이 $29.32 \%$ 이라고 보고한다. 그리고 행사내용이 실제로 공시된 행사공시일을 기준으로 공시효과를 분석한 결과 행사공시일 익일에 음(-)으로 유의적인데 이는 대주주가 지나치게 높은 이익을 실현하는 것에 대한 시장의 부정적인 견해를 반영한다고 해석한다.

$\operatorname{Kim}(2014)$ 은 2002년부터 2010년까지 행사된 경영자스톡옵션 행사를 대상으로 '행사 후 보유', '행사 후 매도', ‘차액현금교부' 등 세 가지 전략으로 구분하여 분석한 결과 경영자에게 유리한 주식성과 패턴이 나타나 행사시점이 전략적으로 선택된다고 주장한다. 그는 경영자가 행사시점을 전략적으로 선택할 수 있는 이유는 경영자가 기업의 미래 성과에 대해 우월한 정보를 보유하기 때문이라고 해석한다.

경영자가 경영자스톡옵션 행사시점을 전략적으로 선택할 수 있다면, 그리고 사채권자로부터 신주인수권을 매입한 대주주 등이 자신의 이익을 극대화하는 신주인수권 행사시점을 선택할 수 있다면, 같은 논리로 전환사채의 소유자도 행사시점을 전략적으로 선택할 수 있을 것으로, 즉 주가가 많이 상승한 시점에서 행사할 것으로 판단된다.

\section{3. 표본구성과 연구방법}

\section{1 표본 구성}

콜옵션 전환사채의 문제점을 분석하기 위한 연구 표본을 구성하기 위하여 먼저 한국거래소의 상장공시시스템(KIND)에서 2013년 10월 31일부터 2018년 12월 31일까지 기간을 대상으로 “전환사채권발행” 으로 검색한 전환사채발행 공시자료로부터 다음의 제약조건을 부여한다. 2013년 10월 31일부터 표본을 구성하는 이유는 본 연구가 확인한 바에 의하면 최초의 사모 
콜옵션 전환사채가 2013년 10월 31일에 크루셜엠스(주)에 의해 공시되었기 때문이다.

(1) 발행기업만이 콜옵션(조기상환권)을 보유하는 경우 제외한다(각주 3 참조).

(2) 금융업은 제외하며 유가증권시장 또는 코스닥시장에 상장되어 있다.

(3) 공시일을 전후하여 -150 일부터 +20 일까지 수익률자료가 존재한다.

(4) 해외전환사채를 제외한 국내 전환사채발행으로 제한하며, 하루에 2 건 이상의 전환사채가 공시되면 한 건으로 통합한다.12) 또한 전환대상이 우선주인 경우 제외한다.

(5) 공모 발행은 제외한다.

(6) 회귀분석에 필요한 변수(총자산, $\mathrm{ROA}, \mathrm{OCF}, \mathrm{LEV}$, 토빈 q비율, 대주주지분율, 변동성 등)의 자료가 존재한다.13)

이상의 조건을 부여한 결과 총 1,496 건의 사모 전환사채 발행 공시자료가 확보되었다(발행기업은 557 개). 1,496 건 중에서 유가증권시장 기업에 의해 공시된 건은 $17.8 \%$ 인 267 건이고 코스닥시장 기업에 의해 공시된 건은 $82.2 \%$ 인 1,229 건이다. 조건 (1)을 적용하는 이유는 매도청구권 (콜옵션)이 부여된 경우와 부여되지 않은 경우로 명확하게 구분하기 위함이다. 발행기업만이 콜옵션을 보유하는 89건의 전환사채는 일단 표본에서 제외되지만 뒤에서 콜옵션 전환사채와 비교할 때 $(<$ 표 $3>$ 의 패널 $\mathrm{C})$ 그리고 회귀분석 $(<$ 표 $6>)$ 에서 추가하여 분석에 이용하기로 한다.

<표 1>은 표본의 연도별 구성과 콜옵션 전환사채가 차지하는 비율을 보여준다. 2014년부터 2018년까지 전환사채의 발행건이 지속적으로 증가한다. 2013년에는 8월 29일까지 사모 분리형 $\mathrm{BW}$ 가 활발히 발행된 관계로 전환사채의 발행이 크지 않았으며, 2013년 10월 31일(최초의 콜옵션 전환사채가 발행된 날) 이후 전환사채는 2014년에 137건이 발행되었으나 2018년에는 408건이 발행되었다. 중요한 것은 이해관계자가 콜옵션을 보유한 콜옵션 전환사채의 비율이다. 전체적으로

\section{〈표 1〉 표본의 구성}

이 표는 표본의 연도별 구성과 콜옵션 전환사채의 비율을 보여준다. 여기서 콜옵션 전환사채는 발행기업 또는 발행기업이 지정한 이해관계인이 콜옵션을 소유한 경우이다(즉, 발행기업만이 콜옵션을 보유하는 경우는 이에 해당되지 않음). 표본기간은 2013.10.31. 2018.12.31.이다.

\begin{tabular}{|c|c|c|c|c|c|}
\hline \multirow{2}{*}{ 연도 } & \multicolumn{2}{|c|}{ 연도별 표본 } & \multicolumn{3}{|c|}{ 콜옵션 전환사채 } \\
\hline & 건수 & 비율 & 건수 & 연도별 & 발행건 대비 비율 \\
\hline 2013 & 15 & $1.0 \%$ & 1 & & $6.7 \%$ \\
\hline 2014 & 137 & $9.2 \%$ & 13 & & $9.5 \%$ \\
\hline 2015 & 219 & $14.6 \%$ & 31 & & $14.2 \%$ \\
\hline 2016 & 357 & $23.9 \%$ & 84 & & $23.5 \%$ \\
\hline 2017 & 360 & $24.1 \%$ & 135 & & $37.5 \%$ \\
\hline 2018 & 408 & $27.3 \%$ & 168 & & $41.2 \%$ \\
\hline 합계 & 1,496 & $100.0 \%$ & 432 & & $28.9 \%$ \\
\hline
\end{tabular}

12) 2 건 이상이 동일한 날에 발행된 경우 발행금액은 합산하지만 나머지 발행조건은 발행금액이 큰 건의 조건을 이용한다(발행금액이 동일하면 만기가 긴 건을 이용함).

13) 회귀분석에 필요한 재무제표 자료는 KISVALUE, 수익률자료는 FnGuide를 이용한다. 
What is Wrong with Convertible Bonds that Provide Call Options to Third Parties?

432건이 발행되었으며 이는 전체 표본 1,496건의 28.9\%를 점유한다. 콜옵션 전환사채는 2013년 에는 2 개월 동안 단 1 건만이 발행되었으나 발행건이 지속적으로 그리고 최근에 급격하게 늘어나 2018년에는 168 건이 발행되어 408건의 $41.2 \%$ 를 점유하고 있다.

1,496 건의 전환사채 발행기업의 기초 통계량은 <표 $2>$ 의 패널 $\mathrm{A}$ 와 같다. 총자산은 자산의 장부가치(억 원)이고, $\mathrm{LEV}$ 는 총부채를 총자산으로 나눈 부채구성비율이다. $\mathrm{OCF}$ 는 현금흐름표상의 영업활동에 의한 현금흐름을 총자산으로 나눈 값이고, $\mathrm{ROA}$ 는 총자산순이익률로 순이익을 총자산으로 나눈 값이고, 토빈 $\mathrm{q}$ 비율 $\mathrm{Q}$ 는 부채의 장부가치에 자본의 시장가치(보통주 시가총액과 우선주 시가총액의 합)를 합산한 후 이를 자산의 장부가치로 나눈 비율로 성장기회의 대용변수이다. 그리고 대주주지분율은 최대주주와 특수관계인의 지분율이다.

먼저, 기존의 연구가 지적하듯이(Yoon, 2020), <표 2>의 패널 A는 전환사채 발행기업의 영업성과가 좋지 않음을 보여준다(ROA 평균은 $-11 \%$ 이고 $\mathrm{OCF}$ 평균은 $-3 \%$ 임). 모든 기업의

\section{〈표 2〉기초 통계량}

총자산은 자산의 장부가치(억 원)이고, $\mathrm{LEV}$ 는 총부채를 총자산으로 나눈 부채구성비율이다. $\mathrm{OCF}$ 는 현금흐름표상의 영업활동에 의한 현금흐름을 총자산으로 나눈 값이고, ROA는 총자산순이익률로 순이익을 총자산으로 나눈 값이고, $\mathrm{Q}$ 는 토빈 $\mathrm{q}$ 비율로, 부채의 장부가치에 자본의 시장가치(보통주 시가총액과 우선주 시가총액의 합)를 합산한 후 이를 자산의 장부가치로 나눈 비율로 성장기회의 대용변수이고 변동성은 공시일 기준 -150 일부터 -21 일까지의 수익률로부터 계산한 표준편차이다. 그리고 대주주지분율은 최대주주와 특수관계인의 지분율이다. 전환주식비율은 전환권 행사로 전환될 주식수를 총발행주식수로 나눈 비율이다. REFIX는 리픽싱이 적용되는 경우 1 의 값을 갖는 더미변수이고, 제 3 자CALL은 이해관계자가 콜옵션을 소유하는 경우 1 의 값을 갖는 더미변수이다. 패널 $\mathrm{A}$ 에서 $\mathrm{ROA}, \mathrm{OCF}$, 토빈 $\mathrm{q}$ 비율의 경우 상하위 각 $1 \%$ 에 대하여 그리고 전환주식비율의 경우 상위 $1 \%$ 에 대하여 winsorization을 실시한다.

\begin{tabular}{lrrrrrr}
\hline \multicolumn{1}{c}{ 변수 } & 평균 & 중앙값 & 최소값 & $25 \%$ & $75 \%$ & 최대값 \\
\hline 패널 A: 발행기업의 특성 & & & & & & \\
\hline 총자산(억 원) & 2,503 & 676 & 79 & 418 & 1,241 & 188,803 \\
$\mathrm{LEV}$ & 0.49 & 0.49 & 0.02 & 0.34 & 0.63 & 1.50 \\
$\mathrm{OCF}$ & -0.03 & -0.02 & -0.41 & -0.09 & 0.04 & 0.20 \\
$\mathrm{ROA}$ & -0.11 & -0.04 & -0.99 & -0.19 & 0.02 & 0.22 \\
median-adjusted OCF & -0.08 & -0.06 & -0.46 & -0.13 & -0.01 & 0.17 \\
median-adjusted ROA & -0.13 & -0.07 & -1.01 & -0.21 & -0.00 & 0.20 \\
$\mathrm{Q}$ & 2.81 & 1.56 & 0.44 & 1.05 & 2.63 & 25.90 \\
대주주지분율 & 0.26 & 0.22 & 0.00 & 0.14 & 0.36 & 0.84 \\
변동성(\%) & 4.05 & 3.92 & 0.00 & 2.89 & 5.06 & 8.36 \\
\hline 패널 B: 전환사채발행 관련 통계량 & & & & & \\
\hline 만기(연) & 3.7 & 3 & 1 & 3 & 4 & 30 \\
발행금액(억 원) & 136 & 70 & 2 & 30 & 139 & 12,848 \\
표면이자율(\%) & 1.55 & 1.00 & 0.00 & 0.00 & 2.00 & 15.10 \\
만기수익률(\%) & 3.45 & 3.00 & 0.00 & 2.00 & 5.00 & 15.10 \\
전환주식비율(\%) & 12.53 & 8.27 & 0.06 & 3.57 & 15.63 & 81.30 \\
REFIX(더미) & 0.9552 & 1 & 0 & 1 & 1 & 1 \\
제3자CALL(더미) & 0.2888 & 0 & 0 & 0 & 1 & 1 \\
\hline
\end{tabular}


한국증권학회지 제49권 3호 (2020)

연도별 $\mathrm{ROA}$ 와 $\mathrm{OCF}$ 의 중앙값을 차감하여 구한 median-adjusted $\mathrm{ROA}$ 와 $\mathrm{OCF}$ 의 평균도 각각 $-13 \%$ 와 $-8 \%$ 로 계산되어 영업성과가 중앙값 조정 후 기준으로도 좋지 않음을 확인 가능하다. 그리고 토빈 $\mathrm{q}$ 비율의 경우 평균과 중앙값은 각각 2.81 과 1.56 인 데 이는 전환사채 발행기업이 평균 이상의 성장기회를 갖는 기업임을 의미한다.14)

패널 $\mathrm{B}$ 는 전환사채 발행과 관련된 통계이다. 평균 만기는 3.7년이다(3년 만기 973건, 4년 만기 148건, 5 년 만기 320 건, 기타 만기 55건). 평균 조달금액은 136 억 원이고 전환주식비율(전환권 행사로 인해 전환될 주식수를 총발행주식수로 나눈 비율임)은 평균이 $12.53 \%$ 로 계산되어 전환사채로 인해 발행주식수의 증가가 결코 작지 않음을 보여준다. 그리고 발행된 전환사채의 표면이자율(액면이자율)은 $1.55 \%$ 이고 만기수익률은 $3.45 \%$ 이다. 특히 표면이자율의 경우 $48 \%$ 를 차지하는 722 건에서 $0 \%$ 이다. 그리고 만기수익률의 경우 $13 \%$ 를 점유하는 195 건에서 $0 \%$ 인 데 이는 최근 전환사채 발행시장이 발행자 우위의 시장임을 의미한다. REFIX(리픽싱이 적용되면 1 의 값을 갖는 더미변수)의 평균은 0.9552 인 데 이는 $1,496 \times 0.9552=1,429$ 건에서 리픽싱조항이 포함됨을 의미한다. 그리고 <표 $1>$ 에서 설명했듯이 제 3 자CALL(제 3 자에게 콜옵션이 부여되면 1 의 값을 갖는 더미변수)의 평균은 0.2888 이다 $(1,496 \times 0.2888=432$ 건 $)$

그리고 전환청구권을 행사하는 공시가 주가에 미치는 영향을 측정하기 위하여 전환청구권행사 공시일 표본을 구한다. 먼저 표본은 한국거래소의 $\mathrm{KIND}$ 시스템에서 “전환청구권의행사"를 보고서명으로 하여 구하며 전환사채 발행 공시표본인 1,496 건을 발행한 기업으로 한정한다. 사모발행 $\mathrm{CB}$ 의 전환시작일은 대체로 발행일로부터 1년 후이고 콜옵션이 2015년부터 본격적으로 활용되므로 2016년부터 2018년까지 3년 동안 전환청구권의 행사공시 1,089건을 분석대상으로 선정한다.

\section{2 콜옵션 전환사채의 기본 구조와 문제점 및 금융감독원의 조치}

현대엘리베이터가 2015년 11월 5일 한국거래소 상장공시시스템(KIND)에 공시한 사모 콜옵션 전환사채권발행결정 공시에 포함된 자료를 이용하여 기본구조를 설명하기로 한다. 권면총액은 2,050 억 원이고 표면이자율과 만기수익률은 각각 $1.6 \%$ 와 $4.0 \%$ 이며 만기일은 2020 년 11 월 6 일(5년 만기)이다. 전환사채를 인수한 사채권자는 이음제 2 호기업재무안정사모투자합자회사 등 3 곳이다. 이표는 매 3 개월마다 총 20 회 지급하며 풋옵션(조기상환청구권), 콜옵션(매도청구권), 리픽싱조항(한도는 최초전환가격의 $70 \%$ 까지이며 매 3 개월마다 리픽싱함)이 부여된 전환사채이다. 풋옵션(조기상환청구권)은 사채권자가 조기상환을 청구할 수 있는 권리이며 발행일 이후 2년이 경과한 시점부터 매 3 개월마다 총 12 회 행사가 가능하다(원금상환비율은 1 차의 $104.9600 \%$ 에서 12 차의 $112.8890 \%$ 까지 12 회의 모든 스케줄과 금액이 명시됨). 청약일은 2015년 11 월 6일이고 전환청구기간은 2016년 11월 6일부터 2020년 11월 5일까지이다. 최초의 전환가격은 53,112원 이므로 전환가능주식수는 2050 억 원 $/ 53112=3,859,768$ 주인데 2016년 2월 전환가격이 48,698원으로 리픽싱되어 전환가능주식수는 4,209,618주로 늘어났다.

14) 표본 기간 동안 모든 상장기업의 토빈 $\mathrm{q}$ 비율 중앙값은 1.04 이다. 
What is Wrong with Convertible Bonds that Provide Call Options to Third Parties?

콜옵션의 경우 회사가 직접 또는 회사가 지정한 자를 통하여 사채의 $40 \%$ 에 대하여 매수할 권리를 가지며 매매대금은 연복리 $6.5 \%$ 의 이율을 적용한다. 15$)$ 만기수익률은 $4 \%$ 인데 콜옵션을 행사하여 인수자(사채권자)가 발행금액의 $40 \%$ 를 회사가 지정한 이해관계자에게 매도하는 경우 인수자는 $6.5 \%$ 를 받게 되어 $2.5 \%$ 에 해당되는 프리미엄을 추가로 얻는다. 현대엘리베이터는 2016년 12월 28일 발행총액의 40\%에 해당되는 820 억 원(현대엘리베이터 보통주 $1,683,847$ 주 (= 820억 원/48,698)로 전환될 수 있으며 매매대금은 871억 원)을 콜옵션을 행사하여 조기상환하고 같은 날 현정은회장과 현대글로벌에게 78 억 원에 콜옵션을 양도(부여)하는 계약을 체결한다.16),17)

경제개혁연대는 현대엘리베이터가 전환사채 820 억을 조기상환한 후 현정은회장과 현대글로벌 에게 매도청구권만을 양도한 것은 실질적으로 법에서 금지하고 있는 워런트를 발행해 현회장 등에게 매각한 것으로 볼 수 있으며, 이는 현회장의 경영권 방어 목적으로 추정된다고 주장한다. 다시 말해서 현행 자본시장법이 공모 분리형 $\mathrm{BW}$ 발행만을 허용하면서 사모 분리형 $\mathrm{BW}$ 의 발행을 금지한 것은 분리된 워런트가 지배주주의 경영권 방어에 악용되지 못하도록 한 취지이므로 현회장에게 부여된 매도청구권은 자본시장법 위반이라고 주장한다. 경제개혁연대는 현회장에게 매도청구권의 권리만을 양도한 것은 실질적으로 워런트를 발행해 지배주주에게 매각한 것으로 볼 수 있어 현행 자본시장법상 금지하고 있는 사모방식의 분리형 $\mathrm{BW}$ 의 워런트 우회발행에 해당하는지 여부에 대한 유권해석을 요청했다.18) 그리고 2018년 11월 금융위원회는 "현행 자본시장법령은 전환사채 발행과 관련 콜옵션 부여와 양도를 제한하는 별도 규정을 두고 있지 않다"고 답변한 것으로 알려졌다.

콜옵션 전환사채의 발행규모가 급격히 늘어남에 따라 금융감독원은 2016년 12월 9일 r기업공시서식 작성기준」을 개정하여 전환사채 콜옵션에 관련된 내용을 기재하도록 요구하였다. 개정이유는 “전환사채권 등의 옵션계약의 공시의무를 명확히 인식할 수 있도록 주요사항보고서 서식상 작성위치를 전진 배치하고, 전환 등에 따른 발행예정주식의 총발행주식수 대비 비율을 기재"로 기재되어 있으며 개정된 구체적인 내용을 그대로 인용하면 다음과 같다.19)

15) 공시자료에 표기된 내용은 다음과 같다: “매매대금은 콜옵션 대상 사채의 인수가액 및 이에 대하여 거래종결일로부터 본 조에 따른 매매대금을 전부 지급하는 날까지 연복리 $6.5 \%$ 의 이율에 따라 산정한 금원을 가산한 금액에서 콜옵션 대상 사채와 관련하여 인수인이 기수령한 표면이자를 차감한 금액으로 한다."

16) 현대엘리베이터 투자판단 관련 주요경영사항(제목: 전환사채 취득 및 전환사채에 대한 매도청구권 양도(부여) 계약 체결 결정), 공시일 2016년 12월 28일.

17) 공시된 내용에 의하면 현대엘리베이터는 콜옵션을 행사하여 발행총액의 $40 \%$ 인 $\mathrm{CB}$ (권면총액 820 억 원)를 871억 원에 매수하고, 같은 날에 매도청구권 양도계약을 체결하는데 양도가액이 78 억 원이다. 즉, 이자와 프리미엄으로 51 억 원을 가산하여 871 억 원에 $\mathrm{CB}$ 를 현대엘리베이터가 먼저 매수하였고 현회장과 현대글로벌은 871 억 원을 $\mathrm{CB}$ 매매대금으로 그리고 78 억 원을 옵션매입비용으로 지불한 것으로 이해된다. 2016년 12 월 28 일의 종가는 52,900 원이고 이후 주가는 12 만 원대까지 상승하였다.

18) 이상의 내용은 2018년 6월 21일자 금융소비자뉴스(http://www.newsfc.co.kr) 기사를 수정 인용한 것이다.

19) 금융감독원 홈페이지 기업공시제도일반 게시판에서 인용함. 


\begin{tabular}{|c|c|c|c|}
\hline \multicolumn{3}{|l|}{ 1. 8. (현행과 같음) } & \\
\hline \multirow{5}{*}{ 9. 전환에 관한 사항 } & \multicolumn{2}{|c|}{ (현행과 같음) } & \\
\hline & \multirow{3}{*}{$\begin{array}{l}\text { 전환에 따라 } \\
\text { 발행할 주식 }\end{array}$} & 종류 & \\
\hline & & 주식수 & \\
\hline & & 주식총수대비 비율(\%) & \\
\hline & \multicolumn{2}{|c|}{ (현행과 같음) } & \\
\hline \multicolumn{3}{|c|}{ 9-1. 옵션에 관한 사항 } & \\
\hline \multicolumn{3}{|l|}{ 10. 19. (현행과 같음) } & \\
\hline \multicolumn{4}{|c|}{$\begin{array}{l}\text { 주1) 주7) (현행과 같음). } \\
\text { 주8) “전환에 따라 발행할 주식”에는 전환에 따라 발행할 주식의 종류(우선주의 경우 의결권 유무 } \\
\text { 포함), 발행예정 주식수, 주식총수 대비 비율을 기재한다. 주식총수 대비 비율은 [발행예정 } \\
\text { 의결권있는 주식수/(사채권 발행일 현재 의결권있는 발행주식총수+발행예정 의결권있는 } \\
\text { 주식수)]에 따라 산정하며, 발행예정 주식이 의결권이 없는 경우에는 기재를 생략할 수 있다. } \\
\text { 주9) 주11) (현행과 같음). } \\
\text { 주12) “옵션에 관한 사항”에는 call option, put option 등의 옵션행사자, 옵션행사시의 수익자, 옵션의 } \\
\text { 구조 등을 상세하게 기재한다. 특히 옵션행사로 인하여 발행회사가 아닌 제 } 3 \text { 자가 만기전에 } \\
\text { 사채권을 취득할 수 있는 경우에는 제 } 3 \text { 자의 성명, 제 } 3 \text { 자와 회사와의 관계, 취득규모, 취득목적 } \\
\text { 등을 자세히 기재하여야 하며, 발행당시 제 } 3 \text { 자가 확정되지 않은 경우에는 제 } 3 \text { 자가 될 수 있는 } \\
\text { 자, 제 } 3 \text { 자가 얻게 될 경제적 이익 등에 관한 사항을 자세히 기재해야 한다. }\end{array}$} \\
\hline
\end{tabular}

2016년 12월에 새로운 공시서식이 발표됨에 따라 발행기업은 2017년초부터 새로운 양식에 의해 공시하고 있다. 그러나 새로운 공시서식이 주식총수대비비율(\%)을 제외하고는 새로운 유용한 정보를 제공하지는 않는다. 주식수는 발행금액을 전환가격으로 나누면 계산되므로 주식수를 구체적으로 적지 않더라도 계산이 가능한 숫자이다. 그리고 옵션에 관한 사항도 새로운 사항이 추가되지는 않는다. 다음은 발행기업의 전형적인 공시내용 예시이다.

매수인이 될 수 있는 제 3 자에 관한 사항

제 3 자의 성명 : 미정

제 3 자와 회사와의 관계 : 미정

취득목적 : 미정

제 3 자가 얻게 될 경제적 이익 : 제 3 자가 될 수 있는 자가 콜옵션을 통하여 취득한 전환사채로

전환권 행사시 최초 전환가액 기준 당사 보통주 0000주를 취득할 수 있게 되며, 최대 리픽싱 조정 후에는 0000 주까지 취득 가능함.

성명, 관계, 목적은 모두 미정으로 기재하며, 경제적 이익은 발행금액, 전환가액, 인수비율, 리픽싱비율에 의해 모두 계산할 수 있는 숫자이다. 따라서 개정된 공시서식이 제공하는 새로운 
What is Wrong with Convertible Bonds that Provide Call Options to Third Parties?

정보는 주식총수대비비율(\%)이 유일하므로 결국 금융감독원은 결국 시장의 우려에 흥내만 내고 할일 다 했다고 치부하는 실정이다.20)

미래에 어떤 관계의 누가 얼마의 경제적 이익을 얻게 되는지 공시시점에서 예측하라고 하는 것은 의미가 없다. 금융당국은 이해관계자가 실제로 콜옵션을 행사하여 전환사채를 취득하는 시점에서 이해관계자가 누구이며, 발행회사와 어떤 관계인지, 콜옵션을 발행회사로부터 얼마에 취득하는지, 그리고 취득한 전환사채의 권면금액과 전환가능한 발행주식수가 얼마인지 등을 자세하게 공시하도록 공시서식 작성기준을 개정해야 한다.21) 현대엘리베이터의 경우 주요경영 사항으로 “매도청구권 양도계약 체결”을 공시하였지만, 현대엘리베이터와 달리 외부 모니터링이 활발하게 이루어지지 않는 대부분의 코스닥기업은 이런 내용을 전혀 공시하지 않고 있는 실정이다.

금융위원회가 이해관계자에게 콜옵션을 부여하는 계약이 자본시장법에 위반되지 않는다고 유권해석을 하지만, 콜옵션 전환사채를 이용하여 최대주주 등이 자신의 지분율을 늘리고 상당한 차익을 얻고 있는 것이 현실이다. 그리고 이런 행태는 분리형 사모 BW에서 제기되었던 우려와 사실상 동일한 내용이다.

\section{3 검증 가설}

Yoon(2015b)은 2009년 7월부터 2012년 말까지 공시된 BW건을 대상으로 554건의 표본을 구성하고 환매기업과 비환매기업으로 구분하여 장단기 공시효과와 기업특성을 비교 분석하였다. 그는 비환매기업은 재무적 곤경이 심한 한계기업인 반면에 환매기업은 대체로 지분을 확대하고자 하는 평균 수준의 수상한 기업이라고 보고한다. 같은 논리로, 전환사채를 발행한 기업의 경우에도 자금조달이 주요 목적인 한계기업과, 자금조달도 필요하지만 지분확대와 이익추구가 목적인 평균 수준의 수상한 기업이 상존하리라 평가된다. 따라서 다음과 같은 첫 번째 가설이 도출된다.

가설 $\mathrm{H1}$ : 콜옵션 전환사채 발행기업은 표준형 전환사채 발행기업에 비하여 영업성과가 우수하여 유리한 조건으로 전환사채를 발행하며 최대주주에게 유리한 리픽싱조항 적용비율도 높다.

여기서 유리한 조건은 액면이자율과 만기수익률이 상대적으로 낮다는 것으로 상대적으로 우수한 기업이라면 당연히 적용될 조건이다. 그리고 리픽싱은 투자자에게 일방적으로 유리한 조항인데 최대주주에게 유리하게 만들기 위하여 리픽싱조항을 더 많이 포함시킬 것으로 예상된다.

Yoon(2015b)은 비환매기업의 BW발행 공시효과가 유의적인 양인 반면 환매기업의 공시효과는 전혀 유의적이지 않다고 보고한다. 반면에 Yoon(2019)은 대주주 등의 특수관계인이 신주인수권을 환매한 249 건으로 제한하고 공시시간을 반영하여 보다 정확하게 공시효과를 측정한 결과

20) 주식총수대비비율도 발행주식총수만 구하면 계산되는 변수이다. 초보 개인투자자가 아닌 이상 투자자가 이 비율도 어렵지 않게 구할 수 있을 것으로 추측된다.

21) Yoon(2019)은 신주인수권 행사 1,230건을 분석하였는데 공시자료에 행사자에 대한 정보가 포함되지 않는다고 한다. 따라서 콜옵션 전환사채의 경우 보다 많은 정보를 공시하도록 규정을 강화할 필요가 있다. 
한국증권학회지 제49권 3호 (2020)

공시효과가 유의적인 음이라고 보고한다. 이는 최대주주 등이 신주인수권만을 환매하는 것에 대한 시장의 부정적인 견해를 반영한다. BW로부터 분리된 신주인수권을 매입하는 것이 사실상 $\mathrm{CB}$ 발행과 연관하여 이해관계자에게 콜옵션을 부여하는 것과 유사하므로 시장은 $\mathrm{CB}$ 의 콜옵션 부여를 부정적으로 해석할 것으로 평가된다. 따라서 다음과 같은 두 번째 가설이 도출된다.

가설 $\mathrm{H} 2$ : 콜옵션 전환사채발행의 공시효과가 표준형 전환사채발행 공시효과보다 유의적으로 작다.

기업은 일반사채를 이용한 자금조달이 용이하지 않으면 옵션부사채(전환사채, 신주인수권 부사채 등)를 발행한다. 그러나 실제로 전환청구권 또는 신주인수권이 행사되면 발행주식수가 증가되어 기존 주주의 지분율이 희석된다. 그리고 발행기업은 현재 주가보다 낮은 가격으로 주식을 발행하여 옵션소유자에게 제공해야 하므로 주가에 부정적인 영향을 미칠 수 있다. 물론 이런 효과는 공시시점에서 전부 반영된다고 이론적으로 애기할 수 있지만, 시장이 항상 이렇게 효율적으로 움직이기는 어려울 것이다. Yoon(2019)은 사모 분리형 BW의 신주인수권이 행사되면 주가가 부정적으로 반응한다고 보고한다. 따라서 전환청구권행사가 공시되면 시장은 부정적으로 반응할 것으로 추정되므로 다음과 같은 세 번째 가설 $3 \mathrm{a}$ 가 도출된다. 그리고 $\mathrm{CB}$ 발행 공시효과에 반영된 콜옵션에 대한 부정적인 시각을 고려할 때 전환청구권행사와 관련된 공시효과에서도 차별적인 효과가 가능하다. 따라서 다음과 같은 세 번째 가설 $3 \mathrm{~b}$ 가 도출된다.

가설 H3a: 전환청구권행사의 공시효과는 부정적이다.

가설 $\mathrm{H} 3 \mathrm{~b}$ : 콜옵션 전환사채 전환청구권행사의 공시효과가 표준형 전환사채 전환청구권행사의 공시효과보다 더 부정적이다.

본 연구는 첫 번째와 두 번째 가설을 검증하기 위하여 전환사채발행 공시표본 1,496 건을 이용하고, 세 번째 가설을 검증하기 위해 전환청구권행사 공시표본 1,089 건을 이용하기로 한다.

\section{4 방법론}

\subsection{1 초과수익률 추정}

전환사채 발행과 관련하여 공시효과를 측정하기 위한 초과수익률 $\mathrm{AR}$ (abnormal return: $\mathrm{AR}$ )은 다음과 같은 시장조정수익률모형(market-adjusted return model)을 이용한다.

$$
A R_{j t}=r_{j t}-r_{m t}
$$

단, $A R_{j t}$ 는 $j$ 기업의 $t$ 일의 초과수익률, $r_{j t}$ 는 $j$ 기업의 $t$ 일의 수익률, 그리고 $r_{m t}$ 는 주가지수의 $t$ 일의 수익률이다. 시장수익률로 종합주가지수(KOSPI) 또는 코스닥지수를 이용한다. 그리고 다음과 같은 시장모형(market model)을 이용한 결과도 추가로 보고한다.

$$
A R_{j t}=r_{j t}-\left(\hat{\alpha_{j}}+\hat{\beta}_{j} r_{m t}\right)
$$


What is Wrong with Convertible Bonds that Provide Call Options to Third Parties?

$\hat{\alpha}$ 와 $\hat{\beta}$ 는 공시일 21 일전부터 150 일전까지의 일별수익률에 적용하여 최소자승법을 통해 추정한다.

그리고 공시일을 전후한 $-k$ 일부터 $+k$ 일까지의 $j$ 기업의 누적초과수익률 CAR(cumulative abnormal return)은 다음과 같이 구하며 평균 $\mathrm{CAR}$ 이 0과 상이한가를 검증하기 위하여 t검증을 실시한다.

$$
C A R(-k,+k)=\sum_{t=-k}^{k} A R_{j t}
$$

\subsection{2 회귀 모형}

콜옵션의 포함 여부가 공시효과에 미치는 영향을 측정하기 위하여 다음의 회귀식을 이용한다. 여기서 종속변수는 누적초과수익률로 3 일, 5 일, 7 일의 누적초과수익률인 CAR3 $(-1,1), \mathrm{CAR} 5(-2,2)$, $\mathrm{CAR} 7(-3,3)$ 을 이용하기로 한다. 이 경우 표본수는 1,496 건(표준형 $\mathrm{CB} 1,064$ 건, 콜옵션 $\mathrm{CB}$ 432건)에 발행기업만이 콜옵션을 보유하는 89건을 추가하여 1,585 건으로 증가한다.

$$
\begin{aligned}
C A R= & \alpha+\beta_{1} \ln (\text { asset })+\beta_{2} L E V+\beta_{3} O C F+\beta_{4} R O A+\beta_{5} Q+\beta_{6} \text { ownership }+\beta_{7} \text { volatility } \\
& +\beta_{8} \ln (\text { amount })+\beta_{9} \text { ratio }+\beta_{10} R E F I X+\beta_{11} \text { 표준 } C A L L+\beta_{12} \text { 제 } 3 \text { 자 } C A L L+\epsilon
\end{aligned}
$$

독립변수에 대한 설명은 다음과 같다.

$\ln ($ asset $)$ : 총자산 장부가치에 자연대수를 취한 값

$L E V$ : 부채의 장부가치를 총자산으로 나눈 부채구성비율

$O C F$ : 현금흐름표상의 영업활동에 의한 현금흐름을 총자산으로 나눈 값

$R O A$ : 순이익을 총자산으로 나눈 총자산순이익률

$Q$ : 토빈의 $\mathrm{q}$ 비율로 부채의 장부가치에 자본의 시장가치(보통주 시가총액과 우선주 시가총액의

합)를 합산한 후 이를 자산의 장부가치로 나눈 비율

ownership: 최대주주와 특수관계인의 지분율

volatility: 공시일 기준 -150 일부터 -21 일까지의 수익률로부터 계산한 표준편차

$\ln$ (amount) : 발행금액에 자연대수를 취한 값

ratio : 전환권 행사로 전환될 주식수를 총발행주식수로 나눈 전환주식비율

REFLX: 리픽싱이 적용되는 경우 1 의 값을 갖는 더미변수

표준 $C A L L$ : 발행기업만이 콜옵션을 소유하는 경우 1 의 값을 갖는 더미변수

제 3 자 $C A L L$ : 이해관계자가 콜옵션을 소유하는 경우 1 의 값을 갖는 더미변수

\section{4. 실증 결과}

\section{1 콜옵션 전환사채 발행기업의 특성}

Yoon(2015a)에 의하면 분리형 사모 신주인수권부사채를 발행한 기업들은 크게 두 가지 
한국증권학회지 제49권 3호 (2020)

유형으로 구분되는데, 첫 번째 유형은 자금조달이 절대적으로 필요한 한계기업이고 두 번째 유형은 자금조달이 절실하게 필요하지 않는 기업으로 제도의 허점을 이용하여 큰 이익을 얻거나 지분을 확보하고자 하는 수상한 기업이다. 같은 논리로, 전환사채를 발행하는 기업도 자금조달이 절실한 한계기업과, 자금조달이 조금 필요하기도 하면서 동시에 제도의 허점을 이용하여 이익을 추구하거나 지분을 확보하고자 콜옵션 전환사채를 발행하는 기업으로 구분된다.

콜옵션 전환사채를 발행하는 기업과 표준형 전환사채를 발행하는 기업을 비교해 보자. 1,496 건의 표본은 콜옵션 전환사채 발행 432 건과 표준형 전환사채 발행 1,064 건으로 구성된다. $<$ 표 3>의 패널 $\mathrm{A}$ 에 의하면, 콜옵션 전환사채를 발행한 기업은 표준형 전환사채를 발행한 기업과 비교하여, 기업규모가 크고, 토빈 q비율은 낮고, 영업현금흐름과 총자산영업이익률이 높고 변동성이 작은 상대적으로 우량한 기업이고, 대주주지분율도 높은 기업이다. 이번에는 콜옵션 전환사채와 표준형 전환사채의 발행조건을 비교해보자. 패널 $\mathrm{B}$ 는 콜옵션 전환사채를 발행한 기업은 발행금액이 크고 전환주식비율이 높으며, 만기는 길고, 표면이자율과 만기수익률이 낮으며 리픽싱조항의 채택비율이 상대적으로 높은 기업임을 보여준다.22), 23) 가장 유의적인 차이가 나는 비율이 표면이자율과 만기수익률이다(t-value가 각각 -11.04 와 -12.26 임). 두 표본간의 차이에 대한 분석은 콜옵션 전환사채를 발행한 기업이 표준형 전환사채를 발행한 기업보다 경영성과가 우수하며 대주주지분율이 높고 상대적으로 좋은 조건으로 전환사채를 발행하며 최대주주에게 유리한 리픽싱조항의 채택비율이 높은 기업임을 명확히 보여준다.24)

콜옵션 전환사채 발행기업의 대주주지분율이 표준형 전환사채 발행기업의 그것보다 유의적 으로 높은 것은 사실이지만 평균 $28.3 \%$ 의 지분율 자체는 그리 높은 편은 아니다.25) 발행기업은 안정적 경영을 위하여 지분율 추가 확보가 절대적으로 필요할 수도 있을 것으로 판단된다. 그러나 지분율 확보가 필요한 상황이더라도 이런 불공정 거래로 간주될 수 있는 콜옵션 전환사채를 통해 최대주주가 지분율을 증가시키는 것이 바람직하다고 생각되지 않는다.

그리고 콜옵션 전환사채 표본 432건을 대상으로 계산한 콜옵션행사한도의 평균은 $39 \%$ 인데(이 값은 표에 제시되어 있지 않음) 이는 이해관계자가 발행된 전환사채의 $39 \%$ 를 차후에 유리하면 인수할 수 있다는 의미이다. <표 2>의 패널 B에서 전환주식비율의 평균이 $12.53 \%$ 이므로 $39 \%$ 의 평균행사한도는 총발행주식수 대비 $12.53 \% \times 0.39=4.9 \%$ 를 의미한다. 총발행주식수의 평균 4.9\%에 해당되는 주식수를 최대주주 등의 이해관계자가 취득할 수 있다는 의미이므로 콜옵션

22) 본 연구에서 전환주식비율은 전환권 행사로 전환될 주식수를 총발행주식수로 나눈 비율이다. 반면에 기업공시서식 작성기준에서 정의된 주식총수대비비율은 전환권 행사로 전환될 전환주식수를 전환 주식수와 총발행주식수의 합으로 나눈 비율이다.

23) 대체로 콜옵션 전환사채(발행기업만이 콜옵션 보유)의 만기가 표준형 전환사채의 만기보다 긴 것으로 알려져 있다(Verwijmeren and Yang, 2020).

24) 추가로 콜옵션 전환사채 표본과 표준형 전환사채 표본 간에 리픽싱 적용 빈도 차이에 대한 $\chi^{2}$ 검증을 실시하였다 $\left(\chi^{2}=4.10\right)$. 귀무가설은 콜옵션 포함여부와 리픽싱 적용비율 간에 상관관계가 없다는 것으로, $\chi^{2}$ 검증결과 귀무가설은 $5 \%$ 수준에서 기각된다.

25) 2014년부터 2018년까지 코스닥기업의 평균 대주주지분율(특수관계인 지분율 포함)은 $36 \%$ 이다. 
What is Wrong with Convertible Bonds that Provide Call Options to Third Parties?

전환사채의 발행이 지배구조에 미치는 영향이 결코 적지 않음을 알 수 있다. 참고로 콜옵션행사 한도가 $100 \%$ 인 경우도 21 건이다.

\section{〈표 3〉 콜옵션 전환사채와 표준형 전환사채 특성 비교}

콜옵션 전환사채는 이해관계자가 콜옵션을 보유하는 전환사채이고 표준형 전환사채는 콜옵션이 부여되지 않은 전환사채이다. 매도청구권 전환사채는 콜옵션 전환사채를 의미하고, 조기상환권 전환사채는 발행기업 만이 콜옵션을 소유하는 전환사채이다. asset은 자산의 장부가치(억 원)이고, LEV는 총부채를 총자산으로 나눈 부채구성비율이다. OCF는 현금흐름표상의 영업활동에 의한 현금흐름을 총자산으로 나눈 값이고, $\mathrm{ROA}$ 는 총자산순이익률로 순이익을 총자산으로 나눈 값이고, 토빈 $\mathrm{q}$ 비율 $\mathrm{Q}$ 는 부채의 장부가치에 자본의 시장가치(보통주 시가총액과 우선주 시가총액의 합)를 합산한 후 이를 자산의 장부가치로 나눈 비율로 성장기회의 대용변수이다. 그리고 대주주지분율 ownership은 최대주주와 특수관계인의 지분율이다. volatility는 공시일 기준으로 -150 일부터 -21 일까지의 수익률로부터 구한 변동성이다. $\ln$ (amount)는 발행 금액에 자연대수를 취한 값이다. coupon은 액면이자율(\%)이고 yield는 만기수익률(\%)이다. 전환주식비율 ratio은 전환권 행사로 전환될 주식수를 총발행주식수로 나눈 비율이다. REFIX는 리픽싱이 적용되는 경우 1 의 값을 갖는 더미변수이다. ${ }^{*},{ }^{* *},{ }^{* *}$ 는 각각 $10 \%, 5 \%, 1 \%$ 수준에서 통계적으로 유의함을 의미한다. 패널 $\mathrm{A}$ : 발행기업 특성 비교

\begin{tabular}{lcccc}
\hline \multicolumn{1}{c}{ 구분 } & $\begin{array}{c}\text { 콜옵션 전환사채(a) } \\
\mathrm{n}=432\end{array}$ & $\begin{array}{c}\text { 표준형 전환사채(b) } \\
\mathrm{n}=1,064\end{array}$ & $\begin{array}{c}\text { 차이 } \\
(\mathrm{a}-\mathrm{b})\end{array}$ & $\mathrm{t}$-value \\
\hline $\ln$ (asset) & 25.299 & 25.041 & 0.258 & $4.50^{* * * *}$ \\
$\mathrm{LEV}$ & 0.489 & 0.485 & 0.004 & 0.37 \\
$\mathrm{OCF}$ & -0.017 & -0.042 & 0.025 & $4.19^{* * *}$ \\
$\mathrm{ROA}$ & -0.061 & -0.127 & 0.066 & $6.68^{* * *}$ \\
$\mathrm{Q}$ & 2.065 & 3.108 & -1.043 & $-5.87^{* * *}$ \\
ownership & 0.283 & 0.252 & 0.031 & $3.44^{* * *}$ \\
volatility & 0.037 & 0.042 & -0.005 & $-5.35^{* * *}$ \\
\hline
\end{tabular}

패널 $\mathrm{B}$ : 전환사채 발행 특성 비교

\begin{tabular}{lcccc}
\hline \multicolumn{1}{c}{ 구분 } & $\begin{array}{c}\text { 콜옵션 전환사채(a) } \\
\mathrm{n}=432\end{array}$ & $\begin{array}{c}\text { 표준형 전환사채(b) } \\
\mathrm{n}=1,064\end{array}$ & $\begin{array}{c}\text { 차이 } \\
(\mathrm{a}-\mathrm{b})\end{array}$ & $\mathrm{t}$-value \\
\hline 만기 & 4.060 & 3.540 & 0.520 & $5.14^{* * * *}$ \\
$\ln ($ amount) & 4.515 & 4.055 & 0.460 & $7.99^{* * *}$ \\
coupon(\%) & 0.768 & 1.866 & -1.098 & $-11.04^{* * *}$ \\
yield(\%) & 2.403 & 3.881 & -1.478 & $-12.26^{* * *}$ \\
ratio & 0.139 & 0.120 & 0.020 & $3.58^{* * *}$ \\
REFIX & 0.972 & 0.948 & 0.024 & $2.29^{* * *}$ \\
\hline
\end{tabular}

패널 C: REFIX 적용 여부

\begin{tabular}{|c|c|c|c|c|}
\hline & \multicolumn{2}{|c|}{ REFIX } & \multirow{2}{*}{$\chi^{2}$ 검증 } \\
\hline & & 미적용 & 적용 & \\
\hline $\begin{array}{l}\text { 매도청구권 전환사채 } \\
(\mathrm{n}=432)\end{array}$ & $\begin{array}{l}\text { 건수 } \\
\text { 열백분율 }\end{array}$ & $\begin{array}{r}12 \\
2.8 \% \\
\end{array}$ & $\begin{array}{r}420 \\
97.2 \% \\
\end{array}$ & \multirow{2}{*}{$\begin{array}{c}\chi^{2}=7.70 \\
(* * *)\end{array}$} \\
\hline $\begin{array}{l}\text { 조기상환권 전환사채 } \\
\quad(\mathrm{n}=89)\end{array}$ & $\begin{array}{l}\text { 건수 } \\
\text { 열 백분율 }\end{array}$ & $\begin{array}{r}8 \\
9.0 \%\end{array}$ & $\begin{array}{r}81 \\
91.0 \%\end{array}$ & \\
\hline
\end{tabular}


한국증권학회지 제49권 3호 (2020)

콜옵션 전환사채가 상대적으로 성과가 좋은 기업에 의해 발행되면서도 표준형 전환사채 발행기업에 비하여 상대적으로 대주주지분율이 높고 리픽싱조항의 채택비율도 높다는 사실은 최대주주가 콜옵션 전환사채를 이용하고자 하는 목적이 엿보인다. 콜옵션 전환사채의 경우 최대주주에게 유리하도록 리픽싱조항을 최대한 활용한다는 주장을 뒷받침하기 위하여 발행 기업만이 콜옵션을 갖는 전환사채와 비교해보자. 발행기업만이 콜옵션을 갖는 경우 이를 조기상환권 전환사채로 그리고 이해관계자도 콜옵션을 갖는 경우 이를 매도청구권 전환사채로 구분하자. 조기상환권 전환사채 표본은 표본기간동안 공시된 89건으로 구성한다. 조기상환권 전환사채 89건과 매도청구권 전환사채 432건의 리픽싱조항 적용 여부를 비교한 결과는 패널 $\mathrm{C}$ 와 같다.

리픽싱조항 적용 여부를 비교한 결과 매도청구권 전환사채의 경우 적용비율은 $97.2 \%$ 이고 이는 조기상환권 전환사채의 적용비율인 $91.0 \%$ 보다 유의적으로 크다. 즉, 적용비율이 전환사채 유형과 상관관계가 없다는 가설은 $1 \%$ 신뢰수준에서 기각된다. Yoon(2020)은 리픽싱조항의 부정적 효과를 지지하는 실증증거를 최초로 제시하며, 이 조항은 투자자에게 지나치게 유리한 조항이므로 혜택을 축소해야 한다고 주장한다. 본 연구는 매도청구권 전환사채를 발행하는 기업이 콜옵션을 보유하는 이해관계자에게 유리하도록 리픽싱 조항을 최대한 활용하고 있는 증거를 제시한다.

결론적으로, <표 3>은 첫 번째 가설인 “콜옵션 전환사채를 발행한 기업은 표준형 콜옵션을 발행한 기업보다 상대적으로 영업성과가 좋아 좋은 조건으로 전환사채를 발행하지만 최대주주 에게 유리한 리픽싱조항의 채택비율이 높다"를 지지하는 결과이다.26)

\section{2 콜옵션이 전환사채발행의 공시효과에 미치는 영향}

Yoon(2020)은 2015년부터 2018년까지의 전환사채발행표본 1,421건을 구성하여 전환사채 발행의 공시효과를 검증한 결과, 전환사채 공시효과가 양 $(+)$ 으로 유의적이라고 보고한다. 본 연구의 경우에도 <표 $4>$ 의 패널 $\mathrm{A}$ 에 의하면 공시일을 전후한 3 일간의 누적초과수익률인 $\mathrm{CAR} 3(-1,1)$ 의 평균이 $4.30 \%$ 이고 $(\mathrm{t}-\mathrm{value}=11.68)$ 중앙값이 $1.05 \%$ 이다. 그리고 $\mathrm{CAR3}$ 이 양인 비율은 56.8\%이다. 또한 CAR5, CAR7, CAR11의 평균은 각각 5.40\%, 5.91\%, 6.80\%이다.

콜옵션 전환사채를 발행하면 최대주주가 콜옵션을 보유하여 사적으로 지분율을 높이거나 많은 이익을 얻게 되므로 이는 최대주주를 제외한 주주에게는 불리하게 작용한다. 따라서 콜옵션 전환사채발행의 공시효과가 표준형 전환사채발행의 공시효과보다 낮을 것으로 예상된다. <표 $4>$ 의 패널 $\mathrm{B}$ 는 두 그룹간 차이에 대한 검증결과이다. 27 ) 콜옵션 전환사채의 $\mathrm{CAR}$ 가 표준형 전환사채와 비교하여 $1.36 \%$ 3.97\% 정도 작고 이 차이는 모두 5\% 수준에서 유의적이다.28)

26) 조기상환권 전환사채와 매도청구권 전환사채 발행기업간 차이가 유의적인 OCF, ROA, ownership, $\ln$ (amount), coupon, yield의 경우 조기상환권 전환사채의 변수값은 표준형 전환사채의 값과 유사하다.

27) 시장모형을 적용해도 <표 4>, <표 6>의 결과는 거의 변함이 없다.

28) 심사자의 강건성 검증 요청에 의해 Fama-French 3 factor model(1993)과 Fama-French 5 factor $\operatorname{model}(2015)$ 을 이용하여 초과수익률을 추정한 결과 <표 4>와 크게 차이나지 않는다(계수 추정에 
What is Wrong with Convertible Bonds that Provide Call Options to Third Parties?

공시효과에 영향을 미칠 수 있는 변수가 많으므로 이번에는 이를 통제한 후 차이가 여전히 유의적인지 검증하기로 한다.

\section{〈표 4〉누적초과수익률 분석}

이 표는 전환사채 공시일을 전후한 누적초과수익률에 대한 결과이다. 초과수익률은 시장조정모형을 이용하여 계산한다. 콜옵션 전환사채는 이해관계자가 콜옵션을 보유하는 전환사채이고 표준형 전환사채는 콜옵션이 부여되지 않은 전환사채이다. ${ }^{*},{ }^{* *},{ }^{* * *}$ 는 각각 $10 \%, 5 \%, 1 \%$ 수준에서 통계적으로 유의함을 의미한다.

패널 $\mathrm{A}$ : 누적초과수익률 $(\mathrm{n}=1,496)$

\begin{tabular}{ccccccc}
\hline \multicolumn{1}{c}{ 변수 } & 평균 & 중앙값 & 최소값 & $25 \%$ & $75 \%$ & 최대값 \\
\hline CAR2 $(-1.0)$ & $0.0380^{* * *}$ & $0.0093^{* * *}$ & -0.3186 & -0.0198 & 0.0586 & 0.6255 \\
CAR3 $(-1,1)$ & $0.0430^{* * *}$ & $0.0105^{* * *}$ & -0.3327 & -0.0271 & 0.0678 & 0.9515 \\
CAR5 $(-2,2)$ & $0.0540^{* * *}$ & $0.0140^{* * *}$ & -0.3754 & -0.0359 & 0.0851 & 1.3093 \\
CAR7 $(-3,3)$ & $0.0591^{* * *}$ & $0.0148^{* * *}$ & -0.4050 & -0.0423 & 0.1009 & 1.4185 \\
CAR11 $(-5,5)$ & $0.0680^{* * *}$ & $0.0127^{* * *}$ & -0.6353 & -0.0556 & 0.1254 & 1.9654 \\
\hline
\end{tabular}

패널 B: 두 그룹간 차이에 대한 t검증

\begin{tabular}{ccccc}
\hline 구분 & $\begin{array}{c}\text { 콜옵션 전환사채(a) } \\
\mathrm{n}=432\end{array}$ & $\begin{array}{c}\text { 표준형 전환사채(b) } \\
\mathrm{n}=1,064\end{array}$ & 차이(a-b) & t-value \\
\hline CAR2 $(-1,0)$ & 0.0282 & 0.0419 & -0.0136 & $-2.43^{* *}$ \\
CAR3(-1,1) & 0.0289 & 0.0487 & -0.0198 & $-2.89^{* * *}$ \\
CAR5(-2,2) & 0.0308 & 0.0634 & -0.0326 & $-3.91^{* * *}$ \\
CAR7 $(-3,3)$ & 0.0308 & 0.0706 & -0.0397 & $-4.19^{* * *}$ \\
CAR11(-5,5) & 0.0401 & 0.0793 & -0.0392 & $-3.33^{* * *}$ \\
\hline
\end{tabular}

<표 5>는 회귀분석에 사용할 변수간의 상관계수를 보여준다. 발행규모 $\ln$ (amount)와 전환 주식비율 ratio간의 상관계수가 0.51 로 가장 크다. 그리고 ROA와 OCF간의 상관계수도 0.48 로 매우 크다.

$<$ 표 6>은 전환사채발행의 공시효과에 영향을 미치는 통제변수를 포함하여 콜옵션 전환사채 발행의 공시효과가 유의적으로 작은지 검증하기 위한 회귀분석 결과이다.29) 먼저 <표 $4>$ 의 단일변량분석과 일관성있게 표준형 전환사채와 콜옵션 전환사채의 공시효과 차이를 통제변수를 포함하여 분석하였으며 결과는 <표 6>의 회귀분석결과 (1), (2)와 같다(표본 1,496건).

먼저 발행기업의 특성을 나타내는 통제변수의 경우 총자산이 작을수록(기업규모가 작을수록), 영업현금흐름이 좋을수록, 그리고 변동성 클수록 누적초과수익률은 크다. 그리고 발행과

-150 일부터 -21일까지의 수익률 이용). 즉, Fama-French 3 factor model(1993)을 적용한 결과, 콜옵션 전환사채의 $\operatorname{CAR}(-1,1)$ 은 0.0247 이고 표준형 전환사채의 $\operatorname{CAR}(-1,1)$ 은 0.0451 이다. 이와 유사하게, Fama-French 5 factor model(2015)을 적용한 결과 콜옵션 전환사채의 $\operatorname{CAR}(-1,1)$ 은 0.0242 이고 표준형 전환사채의 $\mathrm{CAR}(-1,1)$ 은 0.0444 이다.

29) 다중공선성(multicollinearity)의 존재를 확인하기 하여 분산확대인자(variance inflation factor)를 확인한 결과 모두 2 를 넘지 않은 것으로 나타나 다중공선성의 문제는 없는 것으로 판단된다. 
한국증권학회지 제49권 3호 (2020)

관련하여, 발행규모가 클수록 그리고 전환주식비율이 클수록 누적초과수익률이 크다. REFIX는 음의 값을 갖고 10\% 신뢰수준에서 유의적이다. Yoon(2020)은 리픽싱조항이 포함된 경우의 공시효과가 리픽싱조항이 제외된 경우의 공시효과보다 유의적으로 작다고 보고한다.

\section{〈표 5〉상관계수 분석}

다음의 상관계수는 연속변수 간에는 pearson correlation, 연속변수와 더미변수 간에는 polychoric correlation, 그리고 더미변수 간에는 tetrachoric correlation이다. $\ln$ (asset)은 자산의 장부가치(억 원)에 자연 대수를 취한 값이고, $\mathrm{LEV}$ 는 총부채를 총자산으로 나눈 부채구성비율이다. OCF는 현금흐름표상의 영업활동에 의한 현금흐름을 총자산으로 나눈 값이고, $\mathrm{ROA}$ 는 총자산순이익률로 순이익을 총자산으로 나눈 값이고, 토빈 $\mathrm{q}$ 비율은 부채의 장부가치에 자본의 시장가치(보통주 시가총액과 우선주 시가총액의 합)를 합산한 후 이를 자산의 장부가치로 나눈 비율로 성장기회의 대용변수이다. 그리고 대주주지분율인 ownership은 최대주주와 특수관계인의 지분율이고 volatility는 공시일 기준으로 -150 일부터 -21 일까지의 수익률로부터 구한 변동성이다. $\ln (\mathrm{amount})$ 는 발행금액에 자연대수를 취한 값이고, 전환주식비율인 ratio는 전환권 행사로 전환될 주식수를 총발행주식수로 나눈 비율이다. REFIX는 리픽싱이 적용되는 경우 1 의 값을 갖는 더미변수이고, 제 3 자CALL은 이해관계자가 콜옵션을 소유하는 경우 1 의 값을 갖는 더미변수이다. $\mathrm{ROA}, \mathrm{OCF}$, 토빈 $\mathrm{q}$ 비율의 경우 상하위 각 $1 \%$ 에 대하여 그리고 ratio의 경우 상위 $1 \%$ 에 대하여 winsorization을 실시한다. 표본수는 1,496 개이다. ${ }^{*},{ }^{* *}{ }^{* * *}$ 는 각각 $10 \%, 5 \%, 1 \%$ 수준에서 통계적으로 유의함을 의미한다.

\begin{tabular}{|c|c|c|c|c|c|c|c|c|c|c|}
\hline & (1) & (2) & (3) & (4) & (5) & (6) & (7) & (8) & (9) & (10) \\
\hline (1) $\ln$ (asset) & - & & & & & & & & & \\
\hline (2) $\mathrm{LEV}$ & $0.35^{* * *}$ & - & & & & & & & & \\
\hline (3) $\mathrm{OCF}$ & $0.32^{* * * *}$ & 0.02 & - & & & & & & & \\
\hline (4) $\mathrm{ROA}$ & $0.33^{* * *}$ & $-0.17^{* * *}$ & $0.48^{* * * *}$ & - & & & & & & \\
\hline (5) $\mathrm{Q}$ & $-0.28^{* * * *}$ & $-0.08^{* * * *}$ & $-0.28^{* * *}$ & $-0.44^{* * *}$ & - & & & & & \\
\hline (6) ownership & $0.31^{* * *}$ & 0.01 & $0.31^{\text {*** }}$ & $0.30^{\text {**** }}$ & $-0.19^{* * *}$ & - & & & & \\
\hline (7) volatility & $-0.24^{* * *}$ & 0.01 & $-0.12^{* * * *}$ & $-0.15^{* * *}$ & $0.17^{* * *}$ & $-0.14^{* * *}$ & - & & & \\
\hline (8) $\ln$ (amount) & $0.40^{* * * *}$ & -0.04 & $0.22^{* * *}$ & $0.23^{* * * *}$ & $-0.20^{* * * *}$ & $0.26^{* * *}$ & $-0.18^{* * *}$ & - & & \\
\hline (9) ratio & 0.02 & $0.10^{\text {*** }}$ & $0.10^{* * * *}$ & 0.04 & $-0.16^{* * *}$ & $0.15^{* * *}$ & $-0.08^{* * *}$ & $0.51^{* * *}$ & - & \\
\hline (10) REFIX & $-0.01^{*}$ & $-0.01^{*}$ & $-0.09^{*}$ & $-0.08^{*}$ & $-0.06^{*}$ & $-0.09^{*}$ & $0.15^{*}$ & $-0.10^{*}$ & $-0.03^{*}$ & - \\
\hline (11) 제3자CALL & $0.20^{* *}$ & $0.00^{* *}$ & $0.13^{* *}$ & $0.18^{* *}$ & $-0.14^{* *}$ & $0.15^{* *}$ & $-0.18^{* *}$ & $0.27^{* *}$ & $0.22^{* *}$ & $0.16^{*}$ \\
\hline
\end{tabular}

제3자CALL은 (1), (2) 회귀분석에서 음의 값을 갖고 모두 $1 \%$ 신뢰수준으로 유의적이다. 이는 <표 $4>$ 의 단일변량분석의 결과를 그대로 지지하는 결과이다. 구체적으로 제 3 자CALL이 포함되면 전환사채발행의 공시효과인 3 일과 5 일 CAR가 각각 $2.3 \%$ 와 $3.7 \%$ 하락한다. 30$), 31)$

30) 한국채택 국제회계 기준(K-IFRS)에서 전환사채의 전환권 대가는 부채 또는 자본으로 분류 가능하다. 부채로 분류하는 경우 주가변동에 따라 전환권 대가의 평가손익이 반영되므로 이익의 변동성이 커지게 된다. 반면에 자본으로 분류하는 경우 평가손익이 반영되지 않는다. 이처럼 전환권 대가의 회계처리 방식이 체계적으로 다른 패턴을 보이므로 본 연구의 결과에도 영향을 줄 수 있을 것으로 사료된다. 본 연구는 전체 표본에 대하여 회계처리 방식을 일일이 확인할 수 없어 이를 보완하는 방법으로 순이익의 변동성을 구하여 회귀분석에 사용하였으나 결과에 영향을 미치지 않는다. 이를 완벽하게 통제하지 못함은 본 연구의 한계점이며 이는 차후 연구에서 명확하게 분석되기를 희망한다.

31) 부채로 분류하는 경우 주가가 오르면 전환권 가치가 상승하고, 그 차액을 파생상품 손실로 회계처리하기 때문에 현금유출이 없음에도 기업의 손실이 발생할 수 있다. 그러나 자본으로 분류하는 경우 손익이 발생하지 않는다. 
What is Wrong with Convertible Bonds that Provide Call Options to Third Parties?

다 तो A

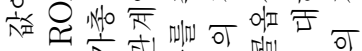

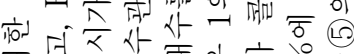

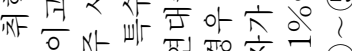

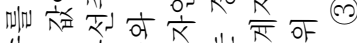

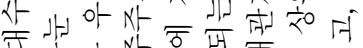

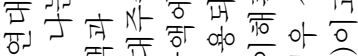

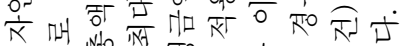

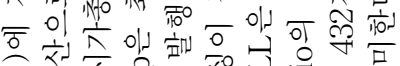

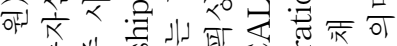

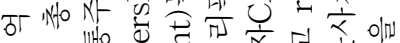

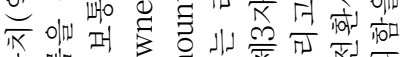

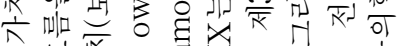
If

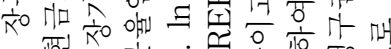

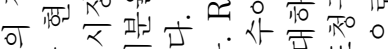

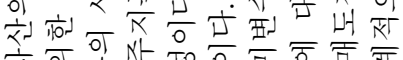

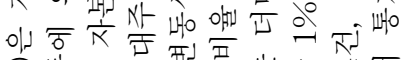

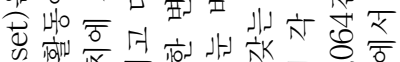

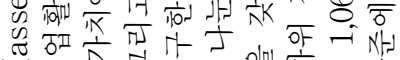
न न रा

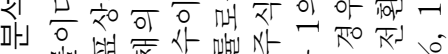

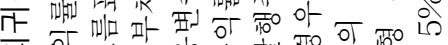
㞹

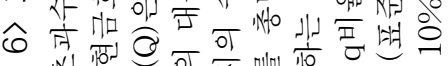

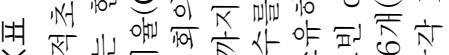

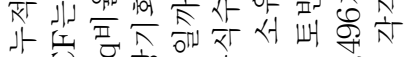
和

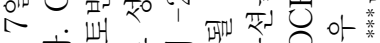
迈顸 대 Ш

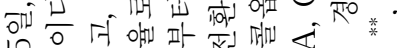

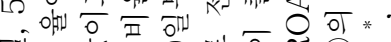

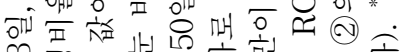

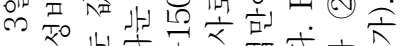

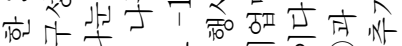

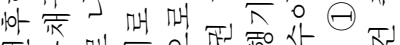

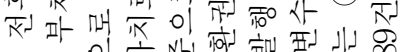

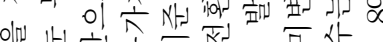

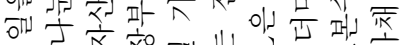
火 n N N

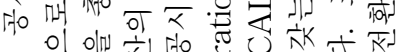

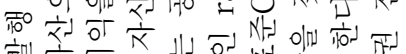

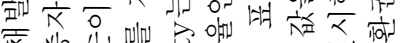
震 N N

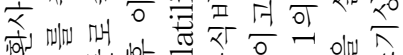
एक

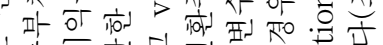

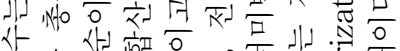

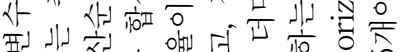

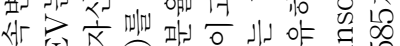

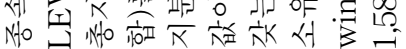

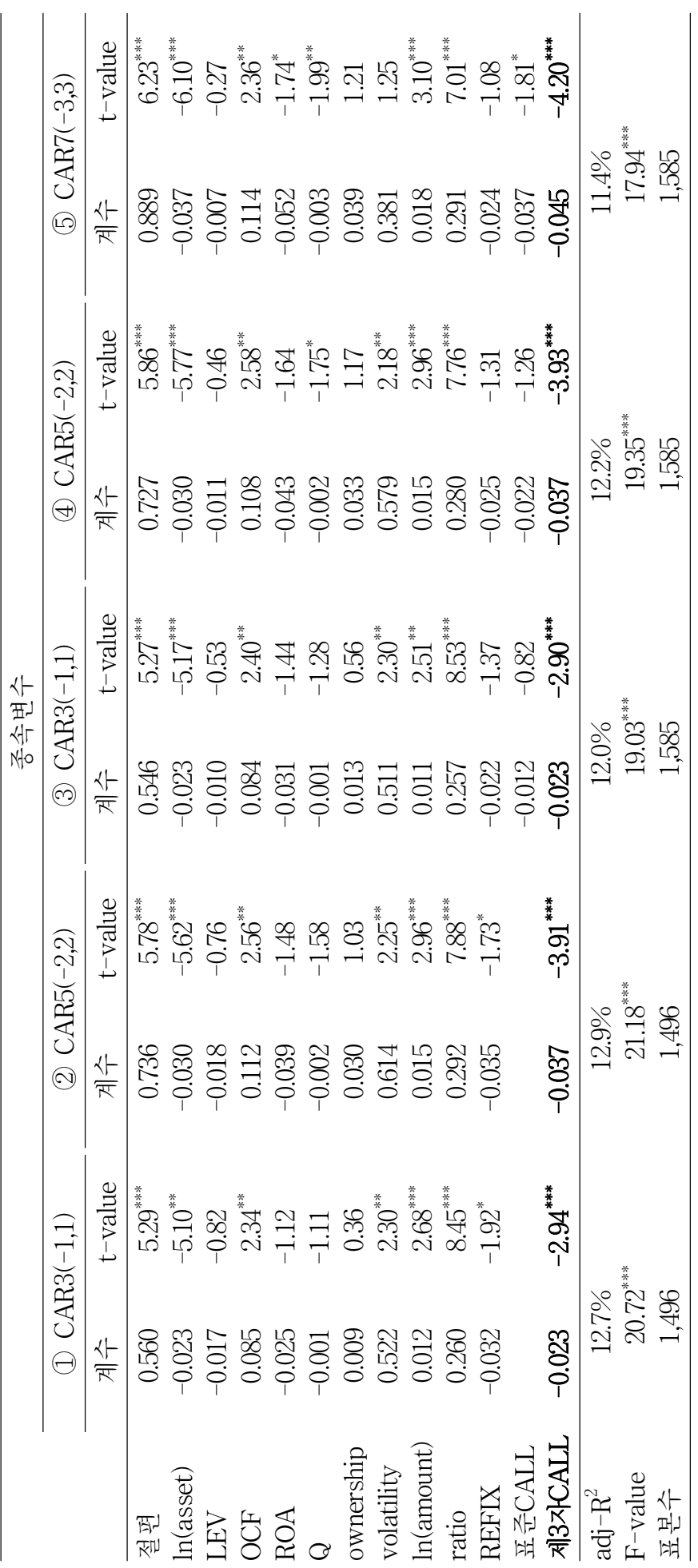


한국증권학회지 제49권 3호 (2020)

이번에는 표본 1,496 건에 발행기업만이 콜옵션을 보유하는 89 건을 추가하여 1,585 건을 대상으로 분석하며 (3) (5)에 적용되는 회귀식은 앞의 식 (4)와 같다. 표준CALL은 발행기업만이 콜옵션을 보유하는 경우 1 의 값을 갖는 더미변수(89건)이고, 제3자CALL은 발행기업뿐만 아니라 대주주 등의 이해관계자도 콜옵션을 보유하는 경우 1 의 값을 갖는 더미변수(432건)이다. 표준CALL 변수는 발행기업만이 콜옵션을 보유하는 전환사채의 공시효과와 표준형 전환사채의 공시효과간의 차이를 반영하게 되고, 제3자CALL변수는 최대주주 등의 이해관계자가 추가적으로 콜옵션을 보유하게 되는 경우의 차이를 반영하게 된다.

(3) (5)의 결과는 (1) (2)의 결과와 유사하다. 다른 점은 토빈Q가 유의적인 음의 값을 갖고 그리고 REFIX가 $10 \%$ 의 유의성을 상실하는 점이다. 표준CALL변수는 음의 값을 갖는데 이는 조기상환권 콜옵션이 부여되면 콜옵션이 부여되지 않는 경우에 비하여 공시효과가 작음을 의미하는데 CAR7의 경우 $10 \%$ 수준에서 유의적이다. 제 3 자CALL변수는 여전히 $1 \%$ 수준에서 음으로 유의적이다.32) 또한 회귀식에 자금조달목적을 추가해도 제3자CALL변수의 유의성은 여전히 유효하다.33)

결론적으로 <표 $4>$ 와 <표 6>의 결과는 “콜옵션 전환사채발행의 공시효과가 표준형 전환사채 발행 공시효과보다 유의적으로 작다”는 두 번째 가설을 지지한다.

\section{3 전환청구권행사의 공시효과}

Yoon(2019)은 신주인수권부사채를 보유한 최대주주 등의 특수관계인과 사채권자가 행사한 신주인수권행사 1,230 건을 분석한 결과, -100 일부터 행사일까지 누적초과수익률이 $29.32 \%$ 이며 행사일 익일의 초과수익률은 $-0.44 \%$ 로 $1 \%$ 수준에서 유의적이라고 보고한다. Yoon(2019)은 신주인수권행사 공시일의 경우 공시시간을 고려하지 않았고 대부분의 행사공시가 장후에 공시되므로 공시일 익일이 사실상 공시일에 해당된다고 보고한다. 본 연구는 Yoon(2019)과

32) 제3자CALL과 REFIX 등 두 더미변수의 교호항(interaction term)을 추가하여 두 변수가 모두 적용되는 경우 증폭효과를 분석하였으나 전혀 유의적이지 않다.

33 <표 3>에 의하면 표준형 전환사채 발행기업과 콜옵션 전환사채 발행기업간에 차이로 인해 두 그룹간 자금조달 목적이 상이할 수 있다. 예를 들어 표준형 전환사채 발행기업은 시설투자와 운영자금 조달을 목적으로 하는 반면에 콜옵션 전환사채 발행기업은 다른 목적(예를 들어 타법인 증권취득)으로 자금을 조달할 수 있다. 우리 표본에서 자금조달목적이 시설투자인 경우 80건, 운영자금조달인 경우 1,008 건, 타법인증권취득자금인 경우 257 건, 그리고 기타인 경우 113 건이고 분류가 불가능한 경우가 38 건이다(한국거래소 상장공시시스템에서 공시자료를 일일이 확인하였으며, 복수의 목적을 표기한 경우 금액이 가장 큰 목적으로 분류함).

자금조달목적을 통제하기 위하여 여러 개의 더미변수를 추가하여 분석하였으나 더미변수는 모두 유의적이지 않고 결과도 거의 차이가 없다. 한편, $\operatorname{Yoon}(2020)$ 은 자금조달 목적으로 구분하여 전환사채의 공시효과를 분석한 결과, 시설자금목적으로 전환사채를 발행하면 공시효과는 전혀 유의적이지 않고, 이는 운영자금목적 또는 타법인증권취득자금목적의 공시효과보다 유의적으로 작다고 보고한다(표본기간: 2015 2018년). 그러나 Kim and Han(2019)은 시설자금목적의 공시효과가 가장 크다고 보고한다(표본기간: 2000 2015년). Kim and Han(2019)은 자금조달목적을 SDC Platinum's Global New Issues Database에서 구한 반면, Yoon(2020)은 한국거래소 상장공시 시스템에 업로드된 공시자료의 '자금조달의 목적' 항목에서 수작업으로 구한 자료를 이용한다. 
What is Wrong with Convertible Bonds that Provide Call Options to Third Parties?

달리 정확한 공시시간을 고려하여 장후에 공시되면 익일을 공시일로 변경한다(Yoon et al., 2017).

사모인 경우 통상 전환청구권은 발행 후 1 년이 지난 시점부터 만기일 1 개월 전까지의 기간에 행사가 가능하다. 전환청구권이 행사되면 발행기업은 이를 공시하는데 전환청구권행사의 공시 효과는 <표 7>과 같다. 앞에서 설명했듯이, 전환사채발행 공시표본을 대상으로 2016년부터 2018년까지 전환청구권 행사내역이 공시된 표본수는 1,089 건이다. 참고로 전환청구권을 행사한 주체에 대한 정보는 제공되지 않는다.

\section{〈표 7〉 전환청구권행사 공시일 전후의 초과수익률 분석}

이 표는 전환사채 소유자가 전환을 청구하는 경우 발행기업이 이 내역을 발표하는 공시일을 전후한 초과수익률을 분석한 표이다. 초과수익률은 시장조정모형과 시장모형을 적용하여 계산된다. 시장모형의 경우 비사건기간은 -150 일부터 -21 일까지이다. 장후에 공시되면 익일을 공시일로 변경한다. *, **, ***는 각각 $10 \%, 5 \%, 1 \%$ 수준에서 통계적으로 유의함을 의미한다. 표본수는 1,089 건이다.

\begin{tabular}{|c|c|c|c|c|}
\hline \multirow{2}{*}{$\begin{array}{c}\text { 전환청구권행사 } \\
\text { 공시일 }\end{array}$} & \multicolumn{2}{|c|}{ 시장조정모형 } & \multicolumn{2}{|c|}{ 시장모형 } \\
\hline & 평균 & $\mathrm{t}$-value & 평균 & $\mathrm{t}$-value \\
\hline-20 & 0.0028 & $2.05^{* *}$ & 0.0024 & $1.75^{*}$ \\
\hline-19 & 0.0043 & $3.09^{* * *}$ & 0.0035 & $2.50^{* *}$ \\
\hline-18 & 0.0027 & $2.12^{* *}$ & 0.0024 & $1.91^{*}$ \\
\hline-17 & 0.0022 & $1.69^{*}$ & 0.0019 & 1.41 \\
\hline-16 & 0.0033 & $2.36^{* *}$ & 0.0026 & $1.89^{*}$ \\
\hline-15 & 0.0001 & 0.11 & -0.0003 & -0.23 \\
\hline-14 & -0.0001 & -0.09 & -0.0007 & -0.48 \\
\hline-13 & 0.0049 & $3.51^{* * *}$ & 0.0041 & $3.01^{* * * *}$ \\
\hline-12 & 0.0052 & $3.43^{* * *}$ & 0.0049 & $3.17^{* * *}$ \\
\hline-11 & 0.0047 & $3.09^{* * *}$ & 0.0040 & $2.64^{* * *}$ \\
\hline-10 & 0.0061 & $4.19^{* * *}$ & 0.0057 & $3.89^{* * *}$ \\
\hline-9 & 0.0024 & $1.73^{*}$ & 0.0017 & 1.23 \\
\hline-8 & 0.0061 & $4.00^{* * *}$ & 0.0057 & $3.67^{* * *}$ \\
\hline-7 & 0.0082 & $5.20^{* * *}$ & 0.0076 & $4.81^{* * *}$ \\
\hline-6 & 0.0057 & $3.94^{* * *}$ & 0.0053 & $3.64^{* * * *}$ \\
\hline-5 & 0.0052 & $3.29^{* * *}$ & 0.0046 & $2.90^{* * * *}$ \\
\hline-4 & 0.0079 & $4.86^{* * *}$ & 0.0073 & $4.39^{* * *}$ \\
\hline-3 & 0.0083 & $5.03^{* * *}$ & 0.0074 & $4.47^{* * *}$ \\
\hline-2 & 0.0129 & $6.82^{* * *}$ & 0.0124 & $6.51^{* * *}$ \\
\hline-1 & 0.0064 & $3.67^{* * * *}$ & 0.0058 & $3.30^{* * * *}$ \\
\hline 0 & -0.0081 & $-5.80^{* * *}$ & -0.0090 & $-6.44^{* * *}$ \\
\hline 1 & 0.0000 & -0.02 & -0.0008 & -0.54 \\
\hline 2 & -0.0016 & -1.06 & -0.0024 & -1.61 \\
\hline 3 & -0.0020 & -1.43 & -0.0026 & $-1.87^{*}$ \\
\hline 4 & -0.0019 & -1.40 & -0.0026 & $-1.95^{*}$ \\
\hline 5 & -0.0004 & -0.27 & -0.0009 & -0.62 \\
\hline
\end{tabular}


〈그림 1〉 전환청구권행사 공시일 전후의 누적초과수익률

이 그림은 1,089 건의 전환청구권행사 공시일을 전후하여 -40 일부터 +20 일까지의 누적초과수익률을 보여준다. 여기서 초과수익률은 시장조정모형으로 추정된다.

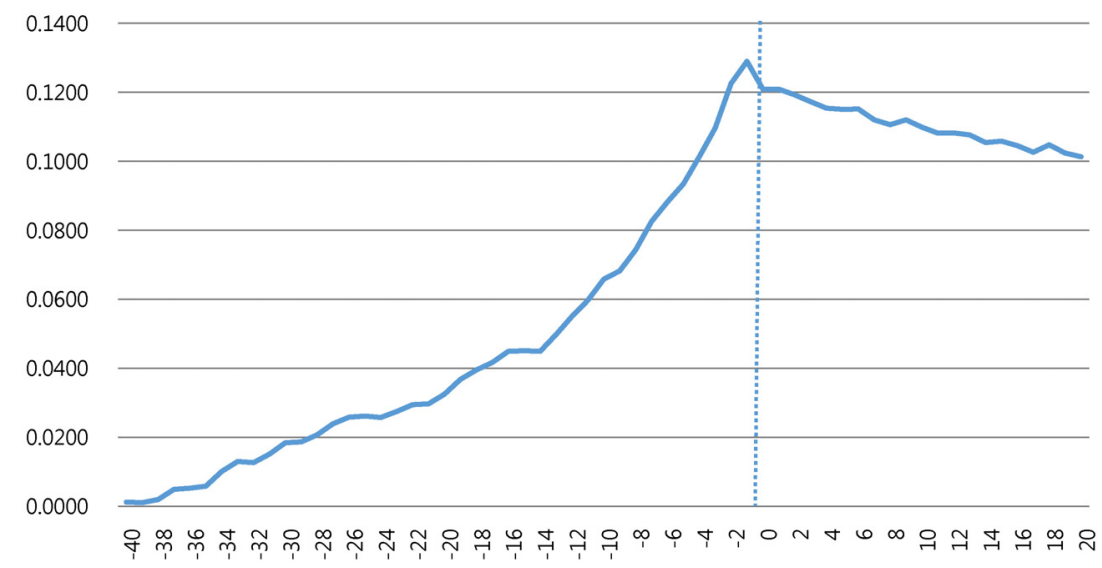

$<$ 표 7>은 전환청구권행사 공시일 전후 -20 일부터 +5 일까지의 일별 초과수익률을 시장조정 모형과 시장모형으로 계산한 결과를 보여준다. 시장조정모형을 적용한 경우 먼저 -20 일부터 -1 일까지 20 일 동안 단 하루(-14일)를 제외하고 초과수익률이 양이며 단 2 일만을 제외하고 적어도 $10 \%$ 신뢰수준에서 유의적이다. -20 일부터 -1 일까지의 누적초과수익률은 $9.93 \%$ 이고 t-value는 14.80 이며, 누적초과수익률이 0보다 큰 비율은 $67 \%$ 이다. 그리고 시장모형의 경우에도 결과는 거의 차이가 없다. <그림 $1>$ 은 공시일을 전후한 주가 패턴을 명확하게 보여준다. 공시일 전에 주가가 유의적으로 그리고 지속적으로 상승하지만 공시일에 주가는 유의적으로 하락하고 이후 다소 천천히 하락하는 움직임을 보인다. -40 일부터 -1 일까지 40 일 동안의 CAR는 $12.90 \%$ 이다. 이는 전환청구권 행사자가 시장보다 우월한 정보를 보유함에 따라 가장 최고점에서 전환청구권을 행사할 수 있다는 증거이다.

전환청구권행사 공시일 전에 양의 초과수익률이 유의적으로 나온 것과는 대조적으로, 공시일에 시장은 공시내용에 대해 매우 부정적으로 반응한다. 공시일의 초과수익률은 $-0.81 \%$ 이고 $\mathrm{t}-\mathrm{value}$ $=-5.80$ 이다(시장모형의 경우 초과수익률은 $-0.90 \%$ 이고 $\mathrm{t}-\mathrm{value}$ 는 -6.44 임). 전환청구권이 행사되면 발행기업에는 전환사채가 보통주로 전환되어 부채가 줄고 자기자본이 늘어나는 긍정적인 효과가 발생한다. 그러나 전환이 이루어지면 발행주식수가 늘어나는 희석효과가 발생하고 전환청구권 행사자는 시가보다 낮은 가격에 보통주를 매입하게 되므로 이는 주가하락을 야기할 수 있다. 또는 전환청구권행사공시가 지금이 주가가 가장 고점이라는 정보를 시장에 전달하게 되므로 이를 반영하여 주가가 하락한다는 것으로도 해석이 가능하다. <표 $7>$ 과 <그림 $1>$ 에 의하면, 전환청구권행사가 공시되면 대상기업의 주가가 유의적으로 하락하므로 이는 전환청구권의 행사가 시장에 부정적인 뉴스를 전달한 것으로 이해되며, 가설 $\mathrm{H} 3 \mathrm{a}$ 를 지지하는 결과이다. 
What is Wrong with Convertible Bonds that Provide Call Options to Third Parties?

\section{4 콜옵션 부여가 전환청구권행사 공시효과에 미치는 영향}

이번에는 콜옵션이 전환청구권행사 공시효과에 미치는 영향을 측정하기 위하여 다음의 절차를 거쳐 표본을 나누기로 한다. 먼저 전환청구권행사공시 1,089 건의 공시내역을 일일이 확인하고 특정 공시일에 1 개 이상의 행사건이 포함되면 그 공시는 제외한다. 공시건당 전환청구권행사가 1 개인 경우는 759 건이고 이는 다시 콜옵션이 포함된 경우인가 아닌가로 구분된다. 이 결과 콜옵션 전환사채와 관련하여 행사된 전환청구권행사공시 202건과 그렇지 않은 557건으로 구분된다.

$<$ 표 8>에 의하면, 전환청구권행사 공시일 초과수익률(AR0)의 경우 콜옵션이 포함되는 경우에 초과수익률이 $-53 \mathrm{bp}$ 낮으며 이는 $10 \%$ 신뢰수준에서 유의적이다. 앞에서의 설명과 일관성있게 콜옵션이 포함되는 경우 시장반응이 더 부정적일 것으로 추정되므로 유의성 검증에서 two-tail 대신에 one-tail을 이용하기로 한다. 그리고 공시일 포함하여 10일간의 누적초과수익률을 비교 하면 차이는 $5 \%$ 신뢰수준에서 유의적이다. 요약하면, 콜옵션 전환사채의 전환청구권행사가 공시되면 이 공시효과는 표준형 전환사채 행사공시효과보다 유의적으로 더 부정적인데, 이는 시장의 부정적인 견해를 반영하며 가설 $\mathrm{H} 3 \mathrm{~b}$ 를 지지한다.34)

〈표 8〉 콜옵션 포함여부가 전환청구권행사 공시효과에 미치는 영향 초과수익률은 시장조정모형을 적용하여 계산된다. 장후에 공시되면 익일을 공시일로 변경한다. * **, ***는 각각 $10 \%, 5 \%, 1 \%$ 수준에서 통계적으로 유의함을 의미한다. 표본수는 759 건이다. p-value는 one-tail을 적용하여 계산한 값이다.

\begin{tabular}{|c|c|c|c|c|c|}
\hline 구분 & $\begin{array}{c}\text { 콜옵션 } \\
\text { 전환사채(a) } \\
\mathrm{n}=202\end{array}$ & $\begin{array}{c}\text { 표준형 } \\
\text { 전환사채(b) } \\
\mathrm{n}=557\end{array}$ & 차이 (a-b) & $\mathrm{t}$-value & $\begin{array}{l}\mathrm{p}^{-} \text {value } \\
\text { (one-tail) }\end{array}$ \\
\hline$\overline{\mathrm{AR} 0}$ & -0.0126 & -0.0073 & -0.0053 & -1.58 & $0.058^{*}$ \\
\hline CAR2 $(0,1)$ & -0.0125 & -0.0062 & -0.0063 & -1.29 & $0.099^{*}$ \\
\hline CAR10 $(0,9)$ & -0.0289 & -0.0080 & -0.0209 & -1.98 & $0.024^{* *}$ \\
\hline
\end{tabular}

\section{5. 결론과 제도적 시사점}

발행회사가 전환사채를 매수할 수 있는 권리를 소유하는 전환사채는 예전부터 우리나라뿐만 아니라 미국, 영국, 일본 등 주요 선진국에서 활발히 발행되는 증권이다 그러나 2013년 우리나라 자본시장에 새로운 형태의 콜옵션 전환사채가 등장하는데 이 전환사채는 발행회사뿐만 아니라 발행회사 최대주주 등의 제 3 자에게도 전환사채를 매수할 수 있는 권리인 콜옵션을 부여하는 전환사채이다. 콜옵션 $\mathrm{CB}$ 는 사모 분리형 신주인수권부사채의 발행이 2013년 8월 29일부로

34) <표 3>에 의하면 콜옵션 전환사채가 표준형 전환사채보다 전환주식비율이 높고 리픽싱비율도 높으므로 전환에 따른 희석효과가 콜옵션 전환사채의 경우 더 크게 되고 이로 인해 <표 8>에서 콜옵션 전환사채 전환청구권행사 공시효과가 표준형 전환사채의 그것보다 더 부정적일 수 있다. 이를 통제하기 위하여 희석효과의 직접적인 척도인 전환주식비율(전환주식수/총주식수)을 회귀분석에 추가한 결과 <표 8>에서의 유의성은 전혀 영향을 받지 않는다. 
한국증권학회지 제49권 3호 (2020)

금지됨에 따라 이를 대체할 상품으로 시장에서 개발되었으며 이후 발행량이 급격하게 증가하고 있다. 예를 들어, 2018 년의 경우 발행된 전환사채의 $41 \%$ 가 이해관계자(또는 제 3 자)에게 콜옵션을 부여하고 있다. 콜옵션 $\mathrm{CB}$ 는 발행기업 또는 발행기업이 지정하는 제 3 자에게 콜옵션을 부여하는 전환사채로, 이해관계자가 보유하는 콜옵션(시장에서 매도청구권으로 불림)은 사모 분리형 $\mathrm{BW}$ 로부터 분리된 신주인수권과 사실상 동일한 효과를 제공한다.

분리형 사모 $\mathrm{BW}$ 의 경우 최대주주 등이 $\mathrm{BW}$ 의 발행과 동시에 신주인수권을 매입하며 매입 가격은 행사가격의 평균 4.6\%이다(Yoon, 2015a). 콜옵션 $\mathrm{CB}$ 의 경우 최대주주 등은 미리 콜옵션을 매입할 필요가 없으며, 차후에 주가가 많이 상승하여 콜옵션이 내가격에 진입하면 최대주주는 발행기업으로부터 콜옵션을 양도받은 후 이를 행사함으로서 항상 이익을 얻는 거래만을 할 수 있다. 사실 최대주주 등이 콜옵션을 얼마에 매입하는지 전혀 공시되지 않으므로 일부의 경우 무상에 가까운 비용으로 최대주주가 콜옵션을 확보하는 것도 가능하다고 본다. 따라서 콜옵션 $\mathrm{CB}$ 를 이용하면 분리형 $\mathrm{BW}$ 를 이용하는 경우에 비하여 콜옵션 매입비용의 지불을 행사시점으로 연기할 수 있고 또한 손해볼 확률이 $0 \%$ 라는 점에서 투자자에게 절대적으로 유리하므로 콜옵션 전환사채는 최악의 불공정 상품으로 평가된다.

본 연구는 콜옵션 전환사채가 처음 공시된 2013년 10월 31일(공시기업 크루셜엠스)부터 2018년 말까지 공시된 전환사채 1,496 건을 대상으로 콜옵션 포함 여부가 발행공시효과와 전환권행사공시 효과에 미치는 영향을 분석하였으며 주요 결과는 다음과 같다. 첫째, 콜옵션 전환사채발행의 공시효과는 표준형 전환사채발행의 공시효과보다 유의적으로 작은데(차이는 2 일 $\mathrm{CAR}$ 의 경우 $-1.36 \%$ 이고 7 일 $\mathrm{CAR}$ 의 경우 $-3.97 \%$ 임) 이는 콜옵션 부여에 대한 부정적인 견해를 반영한다. 둘째, 콜옵션 전환사채를 발행한 기업은 표준형 전환사채를 발행한 기업에 비하여 영업성과가 우수하고 발행조건이 유리하는 등 상대적으로 우량한 기업이지만 대주주지분율이 높고 리픽싱 조항 채택비율도 높다. 대주주지분율이 높은 기업이 콜옵션 전환사채를 이용하여 지분율을 더 높이고자 하며 또한 투자자에게 유리한 리픽싱조항을 더 많이 채택한다는 것은 최대주주의 의도가 건전하다고 보기 어렵다는 것을 의미한다. 셋째, 전환청구권행사의 공시효과는 유의적인 음이며, 콜옵션 전환사채에 포함된 전환청구권행사의 공시효과가 표준형 전환사채에 포함된 전환청구권행사의 공시효과보다 유의적으로 더 부정적으로 나타난다. 요약하면, 본 연구가 보고하는 여러 실증결과는 콜옵션 전환사채에 대한 부정적 견해를 지지한다.

금융감독원은 콜옵션 $\mathrm{CB}$ 의 문제점을 인식하고 2016년 말 공시서식을 변경하였으나 소기의 성과를 얻지 못하고 있다. 사모 분리형 $\mathrm{BW}$ 의 경우에도 문제점을 인식하고 먼저 공시서식을 변경하여 자본시장에 추가적인 정보를 제공하였지만 이는 문제점을 해결할 수 있는 근본적인 대안이 되지 못하였고 결국 감독당국은 분리형 $\mathrm{BW}$ 의 발행을 전면 금지하게 된다. 콜옵션 전환사채에 대한 근본적인 대책을 수립하는데 시간이 많이 소요된다면 우선적으로 콜옵션 부여시(또는 행사시) 이해관계자가 누구이며 얼마의 가격으로 옵션을 매입하는지 등을 명확히 공시하도록 규정을 변경하여야 한다.

본 연구는 콜옵션 전환사채의 발행 현황과 문제점을 처음 체계적으로 제시한다는 점에서 그리고 콜옵션에 대한 시장의 부정적 견해를 반영하는 실증증거를 처음으로 보고한다는 점에서 
What is Wrong with Convertible Bonds that Provide Call Options to Third Parties?

본 연구가 재무 이론과 정책 측면에서 공헌하는 바가 크다고 사료된다. 금융감독원은 사모 분리형 $\mathrm{BW}$ 의 경험을 교훈삼아, 공시서식을 변경하는 수준에서 그칠 것이 아니라 공론화를 통하여 보다 근본적인 대책을 세워야 한다. 전환사채 발행과 관련하여 콜옵션을 양도하는 것이 현재의 자본시장법에 위배되지 않는다 하더라도 최대주주에 의해 악용될 가능성이 매우 높으므로 이를 차단할 수 있는 방안을 강구해야 한다. 그러나 궁극적으로, 사모 분리형 $\mathrm{BW}$ 가 금지된 것처럼 이해관계자에게 콜옵션을 부여하는 사모 콜옵션 전환사채의 발행도 금지되어야 할 것으로 사료된다. 발행기업이 발행된 전환사채를 만기일 전에 상환하는 것은 정상적인 재무결정이므로 당연히 허용되어야 한다. 따라서 콜옵션 전환사채의 발행을 금지한다는 것은 발행기업만이 콜옵션을 보유할 수 있도록 제한하는 것을 의미한다. 
한국증권학회지 제49권 3호 (2020)

\section{References}

Abhyankar, A., and A. Dunning, 1999, Wealth Effects of Convertible Bond and Convertible Preference Share Issues: An Empirical Analysis of the U.K. Market, Journal of Banking and Finance, Vol. 23 (7), pp. 1043-1065.

Agarwal, V., W. Fung, Y. Loon, and N. Naik, 2011, Risk and Return in Convertible Arbitrage: Evidence from the Convertible Bond Market, Journal of Empirical Finance, Vol. 18 (2), pp. 175-194.

Bechmann, K., 2004, Short Sales, Price Pressure, and the Stock Price Response to Convertible Bond Calls, Journal of Financial Markets, Vol. 7 (4), pp. 427-451.

Bechmann, K., A. Lunde, and A. Zebedee, 2014, In- and Out-of-the-Money Convertible Bond Calls: Signaling or Price Pressure?, Journal of Corporate Finance, Vol. 24, pp. 135-148. Brennan M., and E. Schwartz, 1988, The Case for Convertibles, Journal of Applied Corporate Finance, Vol. 1 (2), pp. 55-64.

Burlacu, R., 2000, New Evidence on the Pecking Order Hypothesis: The Case of French Convertible Bonds, Journal of Multinational Financial Management, Vol. 10 (3-4), pp. 439-459.

Byun, J., and K. Park, 2017, The Effect of the Refixing Option in Convertible Bond on Shareholders' wealth, Conference Paper, pp. 485-509. http://www.korfin.org/korfin_file/forum/2017co - conf6-2.pdf.

Choe, H., and C. Yang, 2012, Convertible Bond Arbitrage and Short Sales: Evidence from the Korean Stock Market, Asian Review of Financial Research, Vol. 25 (3), pp. 357-407.

Choi, D., M. Getmansky, and H. Tookes, 2009, Convertible Bond Arbitrage, Liquidity Externalities, and Stock Prices, Journal of Financial Economics, Vol. 91 (2), pp. 227-251.

Dann, L., and W. Mikkelson, 1984, Convertible Debt Issuance, Capital Structure Change and Financing-related Information: Some New Evidence, Journal of Financial Economics, Vol. 13 (2), pp. 157-186.

De Jong, A., M. Dutordoir, and P. Verwijmeren, 2011, Why Do Convertible Issuers Simultaneously Repurchase Stock? An Arbitrage-based Explanation, Journal of Financial Economics, Vol. 100 (1), pp. 113-129.

De Roon, F., and C. Veld, 1998, Announcement Effects of Convertible Bond Loans and Warrant Bond Loans: An Empirical Analysis for the Dutch Market, Journal of Banking and Finance, Vol. 22 (12), pp. 1481-1506.

Duca, E., M. Dutordoir, C. Veld, and P. Verwijmeren, 2012, Why Are Convertible Bond Announcements Associated with Increasingly Negative Issuer Stock Returns? An 
What is Wrong with Convertible Bonds that Provide Call Options to Third Parties?

Arbitrage-based Explanation, Journal of Banking and Finance, Vol. 36 (11), pp. 2884-2899. Eckbo, E., 1986, Valuation Effects of Corporate Debt Offerings, Journal of Financial Economics, Vol. 15, pp. 119-151.

Eom Y., and B. Cho, 2017, The Impact of Convertible Bond Arbitrage on Korean Stock Market Liquidity, Korean Journal of Financial Management, Vol. 34 (3), pp. 125-160.

Fama, E., and K. French, 1993, Common Risk Factors in the Returns on Stocks and Bonds, Journal of Financial Economics, Vol. 33, pp. 3-56.

Fama, E., and K. French, 2015, A Five-Factor Asset Pricing Model, Journal of Financial Economics, Vol. 116 (1), pp. 1-22.

Fields, P., and E. Mais, 1991, The Valuation Effects of Private Placements of Convertible Debt, Journal of Finance, Vol. 46, pp. 1925-1932.

Green, R. C., 1984, Investment Incentives, Debt, and Warrants, Journal of Financial Economics, Vol. 13 (1), pp. 115-136.

Harris, M., A. Raviv, 1985, A Sequential Signalling Model of Convertible Debt Call Policy, Journal of Finance, Vol. 40 (5), pp. 1263-1281.

Ingersoll, J., 1977, An Examination of Corporate Call Policies on Convertible Securities, Journal of Finance, Vol. 32 (2), pp. 463-478.

Jalan, P., and G. Barone-Adesi, 1995, Equity Financing and Corporate Convertible Bond Policy, Journal of Banking and Finance, Vol. 19 (2), pp. 187-206.

Jung, M., and M. Cha, 2009, Convertible Debt Issuance and A Firm's Growth, Korean Journal of Financial Management, Vol. 26 (3), pp. 1-29.

Kang, J., and R. Stulz, 1996, How Different is Japanese Corporate Finance? An Investigation of the Information Content of New Security Issues, Review of Financial Studies, Vol. 9 (1) pp. 109-139.

Kho, B., and R. Park, 2000, An Empirical Analysis on the Abnormal Performance of Security-Issuing Firms in Korea, Korean Journal of Financial Studies, Vol. 27, pp. 439-476.

Kim, H. J., and S. H. Han, 2019, Convertible Bond Announcement Returns, Capital Expenditures, and Investment Opportunities: Evidence from Korea, Pacific-Basin Finance Journal, Vol. 53, pp. 331-348.

Kim, H., 2014, The Study on the Strategic Exercise Timing of Executive Stock Options: Informational Timing vs. Exercise Backdating, Korean Journal of Financial Management, Vol. 31 (1), pp. 55-82.

King, T., D. Mauer, 2014, Determinants of Corporate Call Policy for Convertible Bonds, Journal of Corporate Finance, Vol. 24, pp. 112-134. 
한국증권학회지 제49권 3호 (2020)

Kwak, Y., 2012, An Empirical Analysis of Convertible Bond Issues: Focused on Characteristics of Convertible Bonds and Issuing Firms, Korean International Accounting Review, Vol. 41, pp. 525-548.

Kwon, Y., J. Kim, and H. Choe, 1992, An Analysis of the Relationship between the Stock Market and the Convertible Bond Market in Korea, Korean Journal of Financial Studies, Vol. 14, pp. 485-522.

Lewis, C., R. Rogalski, and J. Seward, 1999, Is Convertible Debt a Substitute for Straight Debt or for Common Equity?, Financial Management, Vol. 28 (3), pp. 5-27.

Lewis, C., R. Rogalski, and J. Seward, 2003, Industry Conditions, Growth Opportunities and Market Reaction to Convertible Debt Financing Decisions, Journal of Banking and Finance, Vol. 27 (1), pp. 153-181.

Magennis, D., E. Watts, and S. Wright, 1998, Convertible Notes: The Debt versus Equity Classification Problem, Journal of Multinational Financial Management, Vol. 8 (2-3), pp. 303-315.

Marle, M., and P. Verwijmeren, 2017, The Long and Short of Convertible Arbitrage: An Empirical Examination of Arbitrageurs' Holding Periods, Journal of Empirical Finance, Vol. 44, pp. 237-249.

Mayers, D., 1998, Why Firms Issue Convertible Bonds: The Matching of Financial and Real Investment Options, Journal of Financial Economics, Vol. 47 (1), pp. 83-102.

Oh, S., and W. Kim, 2012, Different Motives and Different Market Reactions to Convertible Bonds and Bonds with Warrants Issuance in Korea, Conference Paper, pp. 799-835. https://www.earticle.net/Article/A243124.

Park J., and J. Baek, 2003, Corporate Governance of Shareholder Wealth Maximization: An Analysis of Convertible Bond Issues, Korean Journal of Financial Management, Vol. 30 (2), pp. 1-39.

Rahman, M., S. Deshpande, 1997, Convertible Bond Calls by Multinational and Domestic Firms: An Agency Cost Perspective, Journal of Multinational Financial Management, Vol. 7 (1), pp. 43-54.

Stein, J., 1992, Convertible Bonds as Backdoor Equity Financing, Journal of Financial Economics, Vol. 32 (1), pp. 3-21.

Verwijmeren, P., and A. Yang, 2020, The Fluctuating Maturities of Convertible Bonds, Journal of Corporate Finance, Vol. 62, pp. 1-17.

Woo C., 1995, An Empirical Study on Market Reaction According to Announcement of Issuance of Convertible Bonds, Korean Journal of Financial Management, Vol. 12 (1), pp. 93-108. Yoon, P., 2015a, Problems with Privately-placed Detachable Warrant Bonds Issuance System 
What is Wrong with Convertible Bonds that Provide Call Options to Third Parties?

in Korea, Korean Journal of Financial Studies, Vol. 44 (1), pp. 25-51.

Yoon, P., 2015b, The Short-term and Long-term Wealth Effects of Privately-placed Detachable Bond with Warrant Issuances, Korean Journal of Financial Studies, Vol. 44 (3), pp. 517-546.

Yoon, P., 2019, Refixing Option and Privately-placed BW Warrant Returns, Korean Journal of Financial Studies, Vol. 48 (2), pp. 129-155.

Yoon, P., 2020, The Announcement Effects of Convertible Bond Issuances and Refixing Conversion Prices, Korean Journal of Financial Studies, Vol. 49 (2), pp. 285-312.

Yoon, P., and S. Choi, 2018, Earnings Management of Firms that Issued Privately-placed Detachable Warrant Bonds, Accounting Information Review, Vol. 36 (1), pp. 35-58.

Yoon, P., S. Choi, and B. Lim, 2017, Is It Advantageous for Managers to Announce Bad News Outside Trading Hours?, Korean Journal of Financial Management, Vol. 34 (3), pp. 33-59.

Yun, Y., and Y. Jeong, 2001, Studies on the Incentives of Issuing the Convertible Bond: Concerning on Common Stock Converting CB of Manufacturing Firms, Korean Management Review, Vol. 30 (1), pp. 27-45. 